\title{
Clay-Polymer Nanocomposites: Preparations and Utilization for Pollutants Removal
}

\author{
Abdelfattah Amari ${ }^{1,2}{ }^{*}$, Fatimah Mohammed Alzahrani ${ }^{3}\left[0\right.$, Khadijah Mohammedsaleh Katubi ${ }^{3}$, \\ Norah Salem Alsaiari ${ }^{3, *}$, Mohamed A. Tahoon ${ }^{4,5}$ - and Faouzi Ben Rebah $4,6, * \mathbb{C}$
}

1 Department of Chemical Engineering, College of Engineering, King Khalid University, Abha 61411, Saudi Arabia

2 Department of Chemical Engineering, Research Laboratory: Energy and Environment, National School of Engineers, Gabes University, Gabes 6072, Tunisia

3 Chemistry Department, College of Science, Princess Nourah bint Abdulrahman University, Riyadh 11671, Saudi Arabia; fmalzahrani@pnu.edu.sa (F.M.A.); kmkatubi@pnu.edu.sa (K.M.K.)

4 Department of Chemistry, College of Science, King Khalid University, P.O. Box 9004, Abha 61413, Saudi Arabia; tahooon_87@yahoo.com

5 Chemistry Department, Faculty of Science, Mansoura University, Mansoura 35516, Egypt

6 Higher Institute of Biotechnology of Sfax (ISBS), Sfax University, P.O. Box 263, Sfax 3000, Tunisia

* Correspondence: abdelfattah.amari@enig.rnu.tn (A.A.); nsalsaiari@pnu.edu.sa (N.S.A.); benrebahf@yahoo.fr (F.B.R.)

Citation: Amari, A.; Mohammed Alzahrani, F.; Mohammedsaleh Katubi, K.; Salem Alsaiari, N.; Tahoon, M.A.; Ben Rebah, F. Clay-Polymer Nanocomposites: Preparations and Utilization for Pollutants Removal. Materials 2021, 14, 1365. https:// doi.org/10.3390/ma14061365

Academic Editor: Andrea Petrella

Received: 11 February 2021

Accepted: 8 March 2021

Published: 11 March 2021

Publisher's Note: MDPI stays neutral with regard to jurisdictional claims in published maps and institutional affiliations.

Copyright: (c) 2021 by the authors. Licensee MDPI, Basel, Switzerland. This article is an open access article distributed under the terms and conditions of the Creative Commons Attribution (CC BY) license (https:// creativecommons.org/licenses/by/ $4.0 /)$.

\begin{abstract}
Nowadays, people over the world face severe water scarcity despite the presence of several water sources. Adsorption is considered as the most efficient technique for the treatment of water containing biological, organic, and inorganic contaminants. For this purpose, materials from various origins (clay minerals, modified clays, zeolites, activated carbon, polymeric resins, etc.) have been considered as adsorbent for contaminants. Despite their cheapness and valuable properties, the use of clay minerals as adsorbent for wastewater treatment is limited due to many factors (low surface area, regeneration, and recovery limit, etc.). However, clay mineral can be used to enhance the performance of polymeric materials. The combination of clay minerals and polymers produces clay-polymers nanocomposites (CPNs) with advanced properties useful for pollutants removal. CPNs received a lot of attention for their efficient removal rate of various organic and inorganic contaminants via flocculation and adsorption ability. Three main classes of CPNs were developed (exfoliated nanocomposites (NCs), intercalated nanocomposites, and phase-separated microcomposites). The improved materials can be explored as novel and cost-effective adsorbents for the removal of organic and inorganic pollutants from water/wastewater. The literature reported the ability of CPNs to remove various pollutants such as bacteria, metals, phenol, tannic acid, pesticides, dyes, etc. CPNs showed higher adsorption capacity and efficient water treatment compared to the individual components. Moreover, CPNs offered better regeneration than clay materials. The present paper summarizes the different types of clay-polymers nanocomposites and their effective removal of different contaminants from water. Based on various criteria, CPNs future as promising adsorbent for water treatment is discussed.
\end{abstract}

Keywords: water treatment; nanomaterials; adsorbents; clay-polymers nanocomposites

\section{Introduction}

Clean water is a crucial factor of our world and shows a vital role to perform all aspects of life and continuous development [1,2]. Despite the presence of several water sources on earth, clean drinking water resources are limited in many regions of the world. This fact is observed in big cities characterized by large dense populations, and quick industrialization. Related to the quick industrialization, scientists reported the existence of more than 700 carcinogenic and highly toxic inorganic and organic micro-contaminants. They are considered as persistent environmental pollutants non-biotransformable or non-biodegradable. Toxic inorganic metals included for instance chromium, mercury, cadmium, lead, arsenic etc. while 
organic contaminants included drugs, phenols, plasticizers, polybrominated diphenyl ethers, polychlorinated biphenyls, polynuclear aromatic hydrocarbons, and pesticides.

Research efforts have been conducted to remove these contaminants from water/wastewater using several methods such as adsorption [3-5], electrolysis [6], electrodialysis [7], ionexchange [8], reverse osmosis [9], conventional coagulation [10], and chemical precipitation [11]. Many of these methods, such as electrodialysis, electrolysis, ion-exchange, and reverse osmosis, are expensive and cannot be applied in developing countries. Conventional coagulation methods and chemical precipitation cause secondary contaminants requiring an additional treatment and increasing the treatment cost. Interestingly, adsorption is the most attractive process in developing countries due to its lower cost and its high efficiency to remove different types of contaminants. Generally, the selection of the useful adsorbent for water treatments is controlled by many factors such as the adsorption capacity of the material toward the target contaminant, cost/efficiency ratio, and the type and concentration of the contaminants present in water. The selected adsorbent must be available, non-expensive, easily regenerable, and have high selectivity toward target contaminants. Interestingly, the adsorption method produces low quantities of sludge, which is largely produced by other expensive methods like chemical precipitation. Efficient adsorbents from biological, organic or mineral origin have been developed for water treatment. The most important used adsorbents are polymeric resins [12], biomass [13], agricultural wastes [14], industrial by-products, silica beads [15], clay minerals, modified clays [16], zeolites [17], and activated carbon [18]. Among the cited materials, polymeric resins have the ability to adsorb a wide variety of organic, high surface area, wide pore structure range, and can be regenerated with no loss in their adsorption capacities. However, they have some disadvantages mainly the sensitivity to particle size, the poor water dissolution, and the $\mathrm{pH}$ dependence. Their performances are also affected by the specific surface area and the porosity, the type of the used resin and their non-suitability for all aromatic pollutants. Furthermore, they are not suitable for water treatment in developing countries due to their high cost of application.

Due to their cheapness and availability compared to other materials, clay minerals have been considered as adsorbent for the removal of several organic and inorganic contaminants from water [19]. However, their efficiency remains lower compared to activated carbon and zeolites. Generally, the practical use of clay materials as adsorbents is limited due to many factors such as the smaller surface area, the low adsorption tendency toward organic species, the difficulty in recovering clay particles from aqueous solutions, and their reduction after regeneration. In order to overcome these limitations, researchers have developed clay-polymer nanocomposites (CPNs) combining the advantageous characteristics of both clay minerals (cheapness, availability, eco-friendly, large surface area and stability) and polymers (mainly the high adsorption efficiency, high surface area and better regeneration) in a new adsorbent, which is nano-scaled or micro-scaled according to their modification process [20,21]. Interestingly, CPNs showed advanced properties (mechanical strength, low gas permeability and heat resistance) allowing cost reduction and enhancing their efficiencies in removing various contaminants from water. In addition to that, many of these CPNs can be synthesized from green materials, which are considered sustainable [22]. Consequently, it is very important to collect, analyze, and deepen the $\mathrm{CPNs}$ research work in order to develop safe and eco-friendly adsorbents applicable at a large scale for water treatment.

The present paper provides recent data concerning CPNs that have been prepared and used as adsorbents for the removal of pollutants from water/wastewater. All the utilities of CPNs in wastewater treatment will be discussed to clarify the future direction of the research work. This will help promote the development of a strategy for the design of $\mathrm{CPNs}$ adsorbents useful and applicable in water treatment process. 


\section{Structures and Types of Clay Minerals}

Clay minerals are an assembly of crystalline minerals. This structure consists of thin sheets (phyllosilicates) arranged in layers. Layers are composed of octahedral $\left(\left[\mathrm{AlO}_{3}(\mathrm{OH})_{3}\right]^{6-}\right)$ and tetrahedral $\left(\left[\mathrm{SiO}_{4}\right]^{4-}\right)$ sheets connected through sharing of apical atoms of oxygen. Clay minerals layers stack via Van der Waals attractions to form interlayer. Clay minerals are classified into seven classes (Table 1): (i) fibrous-layered silicates such as sepiolite and palygorskite, (ii) 1:1 ratio of $\left[\mathrm{AlO}_{3}(\mathrm{OH})_{3}\right]^{6-}$ octahedral and $\left[\mathrm{SiO}_{4}\right]^{4-}$ tetrahedral sheets called kaolinite class such as serpentine, halloysite, and kaolinite, (iii) 2:1 non-expanding class in which the ratio between $\left[\mathrm{SiO}_{4}\right]^{4-}$ tetrahedral and $\left[\mathrm{AlO}_{3}(\mathrm{OH})_{3}\right]^{6-}$ octahedral sheets is 2:1 such as illite and mica, (iv) 2:1 uncharged class such as talc and pyrophyllite, (v) strongly expanding 2:1 class such as montmorillonite, (vi) limited expanding 2:1 class such as vermiculite, (vii) 2:1:1 class in which there is an extra brucite octahedral sheet sandwiched to form a 2:1 composition [23,24].

Table 1. Classification of clay minerals $[23,24]$.

\begin{tabular}{|c|c|c|}
\hline Classes & Structure & Formulas \\
\hline Kaolinite and serpentine & two-sheet phyllosilicates & $\begin{array}{c}\text { kaolinite } \mathrm{Al}_{4}\left[\mathrm{Si}_{4} \mathrm{O}_{10}\right](\mathrm{OH})_{8} \\
\text { serpentine } \mathrm{Mg}_{6}\left[\mathrm{Si}_{4} \mathrm{O}_{10}\right](\mathrm{OH})_{8}\end{array}$ \\
\hline Micas & three-sheet phyllosilicates & ${ }_{2} \mathrm{Al}_{4}\left[\left(\mathrm{Si}_{>6} \mathrm{Al}_{<2}\right) \mathrm{O}_{20}\right](\mathrm{OH})_{4} \cdot \mathrm{nH}_{2} \mathrm{O}$ \\
\hline Vermiculite & $\begin{array}{l}\text { expanding three sheet } \\
\text { phyllosilicates }\end{array}$ & $\left(\mathrm{Mg}, \mathrm{Fe}^{2+}, \mathrm{Fe}^{3+}\right)_{6}\left[(\mathrm{Si}>\mathrm{Al})_{8} \mathrm{O}_{20}\right](\mathrm{OH})_{4} \cdot \mathrm{nH}_{2} \mathrm{O}$ \\
\hline Smectites & $\begin{array}{l}\text { strongly expanding } \\
\text { three-sheet phyllosilicates }\end{array}$ & $\begin{array}{c}\text { montmorillonite: } \\
\mathrm{M}^{+}{ }_{x+y}\left(\mathrm{Al}_{1} \mathrm{Fe}^{3+}\right)_{4-\mathrm{y}}\left(\mathrm{Fe}^{2+}{ }_{,} \mathrm{Mg}_{\mathrm{y}}\left[\mathrm{Si}_{8}-{ }_{\mathrm{x}} \mathrm{Al}_{\mathrm{x}} \mathrm{O}_{20}\right] \cdot(\mathrm{OH})_{4} \cdot \mathrm{nH}_{2} \mathrm{O},\right. \\
\text { beidellite: } \mathrm{M}^{+}{ }_{x} \mathrm{Al}_{4}\left[\mathrm{Si}_{8}-{ }_{x} \mathrm{Al}_{\mathrm{x}} \mathrm{O}_{20}\right](\mathrm{OH})_{4} \cdot \mathrm{nH}_{2} \mathrm{O} \\
\text { nontronite: } \mathrm{M}^{+}{ }_{x} \mathrm{Fe}^{3+}\left[\mathrm{Si}_{8}-{ }_{x} \mathrm{Al}_{\mathrm{x}} \mathrm{O}_{20}\right](\mathrm{OH})_{4} \cdot \mathrm{nH}_{2} \mathrm{O} \\
\text { saponite: } \mathrm{M}^{+}{ }_{x} \mathrm{Mg}_{6}\left[\mathrm{Si}_{8}{ }_{-x} \mathrm{Al}_{\mathrm{x}} \mathrm{O}_{20}\right](\mathrm{OH})_{4} \cdot \mathrm{nH}_{2} \mathrm{O} .\end{array}$ \\
\hline Pyrophyllite and talc & $\begin{array}{l}\text { nonswelling three-sheet } \\
\text { phyllosilicates }\end{array}$ & $\begin{array}{c}\text { pyrophyllite: } \mathrm{Al}_{4}\left[\mathrm{Si}_{8} \mathrm{O}_{20}\right](\mathrm{OH})_{4} \\
\text { talc: } \mathrm{Mg}_{6}\left[\mathrm{Si}_{8} \mathrm{O}_{20}\right](\mathrm{OH})_{4}\end{array}$ \\
\hline chlorites & four-sheet silicates & $\mathrm{Al}_{4}\left[\mathrm{Si}_{8} \mathrm{O}_{20}\right](\mathrm{OH})_{4} \mathrm{Al}_{4}(\mathrm{OH})_{12}$ \\
\hline Palygorskite and sepiolite & sheet-fibrous structure & $\begin{array}{l}\text { palygorskite: } \mathrm{Mg}_{5}\left[\mathrm{Si}_{8} \mathrm{O}_{20}\right](\mathrm{OH})_{2}\left(\mathrm{OH}_{2}\right)_{4} \cdot 4 \mathrm{H}_{2} \mathrm{O} \\
\text { sepiolite: } \mathrm{Mg}_{8}\left[\mathrm{Si}_{12} \mathrm{O}_{30}\right](\mathrm{OH})_{4}\left(\mathrm{OH}_{2}\right)_{4} \cdot \mathrm{nH}_{2} \mathrm{O}\end{array}$ \\
\hline
\end{tabular}

These clay minerals carry positive and negative charges due to isomorphous substitution of octahedral and tetrahedral sheets. Matrix and support of clay-polymers nanocomposites are provided by 2:1 class silicates like saponite, hectorite, and montmorillonite as well as palygorskite. These types of clay minerals are nano-scaled either in fiber diameter or in sheet thickness. Interestingly, organic compounds can be used for the modification of clay minerals to produce organoclays and this represents the first step of clay-polymer nanocomposites synthesis. Natural clay minerals are characterized by its hydrophilicity that allowed their saturation with lithium and sodium cations. Also, this hydrophilicity makes clay minerals incompatible with non-polar polymers but compatible with hydrophilic polymers like polyvinyl alcohol and polyethylene oxide [23]. Thus, non-polar polymers were made compatible with hydrophilic clay minerals via the synthesis of organoclays as preliminary stage. The conventional method of organoclays preparation is the combination of sulfonium, phosphonium, and ammonium with clay minerals [25]. Ion-exchange reaction is used to replace clay minerals cations by positively charged surfactant like hexadecyl trimethylammonium to make clay hydrophobic and allow its modification with hydrophobic polymers. Polar-nonpolar partition mechanisms provided to natural clay minerals via organoclays are known to improve the adsorption capacity of pollutants. Also, they allow an intercalation of pollutants and an increase of positive charges over clay minerals surfaces, which improve the chelation power [26]. 
Because of their cheapness, availability, and valuable properties, clay minerals are of large interest for their potential applications in various areas such as wastewater treatment. However, the application of clay minerals is limited due to many factors (low surface area, regeneration, and recovery limit, etc.) $[19,22]$.

\section{Nanocomposites of Clay-Polymers}

Clay minerals can be used to enhance the performance of polymeric materials. The combination of clay minerals and polymers is considered as promising reinforcements to produce clay-polymer nanocomposites with advanced properties useful for pollutants removal. There are three main classes of nanocomposite clay-polymers; (i) exfoliated nanocomposites, (ii) intercalated nanocomposites, and (iii) phase-separated microcomposites [26]. In the exfoliated nanocomposites, the clay layers are fully dispersed within the polymer matrix. They are composed of $\sim 1 \mathrm{~nm}$ clay layers separated within the matrix of polymer. In intercalated nanocomposites, the silicate crystalline layers are inserted within the polymeric chains to form nano-scaled clay-polymer composite. The phase-separated microcomposite, resulted from embedded polymer inside silicate layers, have similar properties as conventional microcomposites. This polymer nanocomposites display exceptional properties regarding the biodegradability, self-extinguishing behavior, heat distortion, flexural properties, tensile strength, and high modulus. CPNs may include many polymers in their fabrication like chitosan (CS), polystyrene, polypropylene, polyesters, polyurethanes, epoxies, and polyvinyl chloride (PVC).

\subsection{Clay-Polymers Magnetic Nanocomposites}

Polymer matrix of CPNs could be filled with magnetic nanoparticles (NPs) to develop their functionality. For instance, magnetically coated nanoparticles were prepared by casting mix of oleic-acid-coated nanoparticles, poly(butyl acrylate) emulsion, and clay (laponite) [27]. However, this nanocomposite with low content of oleic acid exhibits greater saturation magnetization than that of pure oleic acid-coated magnetic nanoparticles component. This magnetic composite was synthesized via three steps; first, clay dispersion and mixed polymer were transformed into gel. Then, oleic acid-magnetic NPs and polymer were separately fixed in clay platelets and finally, all materials were merged in the main composite. Thus, polymeric matrix is used to fix oleic acid magnetic NPs and clay to produce exclusive nanomaterial. In another work, palygorskite-iron-oxide magnetic nanocomposite was synthesized via environmentally safe and economical precipitation synthesis [28].

\subsection{Clay-Biopolymers Nanocomposites}

Biopolymers (polynucleotides, nucleotides, polypeptides, polysaccharides, and proteins, etc.) are green and biocompatible materials useful in the synthesis of clay NCs with improved properties like functionality and reactivity. The improved properties offered by biopolymers allowed the application of the clay-biopolymers nanocomposites in different fields like packaging materials, tissue engineering, drug delivery, controlled pesticide, and electrochemical sensing. Chitosan is an example of biopolymers extracted from crustacean seafood wastes [29] and composed of units of $\mathrm{N}$-acetylglucosamine and glucosamine. This biopolymer was used for the synthesis of clay nanocomposite useful for the removal of pollutants from water [30]. The synthesis of clay-chitosan nanocomposite was described in another work [31] as shown in Figure 1.

\subsection{Nanoclay of Polyacrylamide-Polymers Nanocomposites}

Bentonite nanoclay polymer composite was synthesized using acrylic acid. First, alkali medium was used for the synthesis of acrylamide from acrylic acid. Then, bentonite was added in nitrogen atmosphere and cross-linking reactions were carried out via $N, N^{\prime}$ methylenebisacrylamide. After that, the polymerization reaction was carried out at $70{ }^{\circ} \mathrm{C}$ in the presence of $\left(\mathrm{NH}_{4}\right) \mathrm{S}_{2} \mathrm{O}_{8}$ in order to produce the nanoclay-polymer [32]. The charac- 
terization of the obtained composite using various methods (Fourier transform infrared spectroscopy, scanning electron microscopy, and X-ray diffraction) showed a complete exfoliatation and dispersion of the bentonite layers in the composite after the polymerization, leading to an increase of the surface area. The new composite can be exploited in many fields such as agriculture [32].

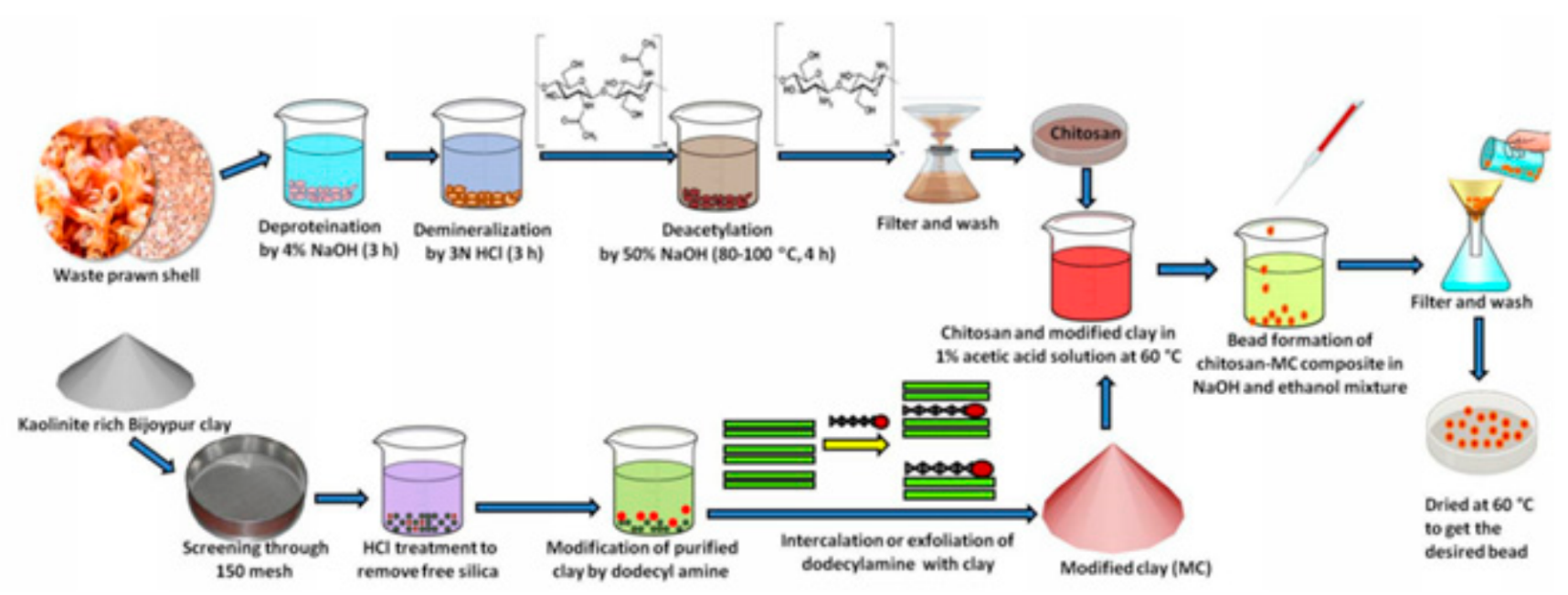

Figure 1. The scheme of clay-chitosan nanocomposite synthesis [31].

\subsection{Nanocomposites of Clay-Polysiloxane}

Organoclays were usually used as matrix during the synthesis of NCs silicate-polysiloxane in the presence of little amount of $\mathrm{H}_{2} \mathrm{O}$. Silanol terminated poly (dimethylsiloxane) was mixed with organo- montmorillonite, which is a mix of dimethyl ditallowammonium alkyl chains of $\mathrm{C} 12, \mathrm{C} 14, \mathrm{C} 16$, and C18 and cross-linked with tetraethylorthosilicate in the presence of catalyst to form NCs of silicate-polysiloxane [33]. The production of exfoliated NCs needs water and the mixing of the modified clay with silanol-terminated poly(dimethylsiloxane) should be carried out under sonication. Moreover, the nature of the clay modifier and silicon affects considerably the NCs synthesis. Hence, the absence of exfoliation and intercalation when montmorillonite is modified with benzyl dimethyloctadecylammonium cation was reported. Also, the use of silanol-terminated poly(dimethylsiloxane) containing only $14 \%(\mathrm{~mol} / \mathrm{mol})$ of diphenylsiloxane units showed only intercalation. Therefore, the optimization of the layered silicate exfoliation required right fitting between the matrix and organoclay [33].

\subsection{Nanocomposites of Clay-Polystyrene}

Polystyrene-clay composites were produced using the addition polymerization technique [34]. A vinyl monomer-montmorillonite intercalate was synthesized by the cation exchange process. Then, free-radical polymerization of styrene in the presence of vinyl monomer-montmorillonite intercalate was achieved leading to the production of polystyrenemontmorillonite materials. The solvation of vinyl monomer-montmorillonite intercalate using acetonitrile enhance the intercalation of styrene between the vinyl monomer- montmorillonite [34]. According to Vaia and Giannelis (1997), the melt intercalation is the best efficient method for the intercalation of polymer into organoclay [35]. The intercalation of polymers depends on the length of the alkyl chain in alkylammonium-exchanged smectites and on the annealing temperature. Under $160^{\circ} \mathrm{C}$, no intercalation was reported for chain having less than 12 carbon atoms. At $180^{\circ} \mathrm{C}$, intercalation occurred independently of the carbon atom number. However, it was reported that the intercalation was not affected by the molecular weight of the polystyrene [35]. 


\subsection{Blends of Organoclay-Polymer}

Organoclay with polymer blends such as poly(l-lactide), poly(e-caprolactone)-clay, and poly-ethylene oxide-clay blends were prepared as reported by Ogata et al., (1997) [36] Distearyl dimethylammonium-modified montmorillonite was mixed and blended with pellets of poly(l-lactide) in warmed chloroform. A 100-mm thick film was formed after evaporation of chloroform. Tactoids of unmodified montmorillonite were aligned on the surface of the film while intercalation of poly(l-lactide) into modified montmorillonite was absent [36]. The modified clay produced an interesting geometric superstructure (tactoids with several silicate monolayers) showing the enhancement of the Young's modulus of the poly(l-lactide)-based composites. Also, storage and loss moduli were enhanced [36].

\subsection{Hybrid Clay-Polyimide}

Clay-polyimide NCs were synthesized by polymerization using pyromellitic dianhydride and 4,4'-diaminodiphenyl ether in dimethylacetamide solution and in the presence of organoclay [37]. The synthesized polyimide-clay nanocomposites with limit fraction of organoclay $(2 \% \mathrm{wt} / \mathrm{wt})$ showed remarkable reduction in the permeability of several gases $\left(\mathrm{H}_{2} \mathrm{O}, \mathrm{O}_{2}, \mathrm{CO}_{2}\right.$, etc.). Moreover, the increase in ratio of the clay mineral caused a decrease of thermal expansion coefficient and montmorillonite exhibited great exfoliation when NCs were synthesized [37].

\subsection{Nanocomposites of Clay-Epoxy}

To improve the solvent resistance and thermal stability of NCs, highly expanded onium-modified clay minerals were diffused into epoxide [38]. Epoxy support was formed using catalytic curing agents, anhydride, aromatic amines, and aliphatic amines having wide glass-transition temperature. Interestingly, new type of exfoliated structure was observed and the matrix tensile properties were improved by the reinforcement offered by the silicate nanolayers. The tensile properties of the resulted nanocomposites (epoxy-magadiite elastomeric) are comparable to other smectite clays [38].

\subsection{Nanocomposites of Clay-Polyurethane}

The solvation process allowed the intercalation of polyols into onium modified organoclays. Structure and length of onium ions greatly affected the intercalation process. The polymerization process of polyolisocyanate precursor-organoclay allowed the production of NCs with clay phase (50 ̊ basal spaces) intercalated in the cross-linked polyurethane network. An interesting benefit was observed with montmorillonites exchanged with chain onium ions containing a number of carbon atoms more than 12 . The produced NCs showed higher toughness and strength compared to pristine polymer NCs [39].

Here, we reported the techniques used to develop nanocomposites of clay-polymers. Using clay minerals, significant technical advantages were achieved (mechanical, thermal, degradative, rheological properties, etc.) allowing the improvement of the new materials. The improved materials can be explored as novel and cost-effective adsorbents for the removal of organic and inorganic pollutants from water/wastewater.

\section{Clay-Polymers Nanocomposites for Pollutants Removal}

Based on their improved performances, CPNs showed the ability to remove various pollutants (bacteria, metals, phenol, tannic acid, pesticides, dyes, etc.) from water/wastewater. Below, the pollutant removals reported in the literature will be discussed.

\subsection{Biological Pollutants Removal}

Drinking water containing microbes, such as Entamoeba histolytica, Shigella sp., and Salmonella typhi, is responsible for dangerous water borne infections such as diarrhea, dysentery, and typhoid [40]. The reduction of pathogen population was traditionally ensured by the chlorination technology. However, nowadays, this technology becomes less used due the existence of soluble organic pollutants that allowed the formation of secondary toxic 
contaminants (chlorophenols, haloacetic acids, trihalomethanes, etc.) [41]. Also, chloramination process showed a higher potential to form nitrosamines than chlorination. Earlier, the use of sand slow filtration was suggested but with limited efficiency due to high cost of filter repair and blocking [42]. Interestingly, composites of clay-polymers were used for antimicrobial activity but the used polymers must be soluble. For instance, antimicrobial efficiency of copper-doped montmorillonite low-density polyethylene (LDPE) nanocomposites toward E. coli was examined [43]. The prepared CPNs contain montmorillonite- $\mathrm{Cu}^{+2}$ complex allowed high antimicrobial activity against $E$. coli $(99 \%)$. Cell death was suggested via complexation between microbial nucleic acids and proteins with copper ions [44].

Similarly, other CPNs such as montmorillonite- polydimethyloxane-chlorhexidine acetate, and clay-polydimethyloxane-chitosan-silver showed the ability to retard the growth of different bacterial strains (E. coli, Candida albicans, Pseudomonas aeruginosa, and Staphylococcus aureus) [45-48]. E. coli was also removed via bentonite clay composite modified with starch-grafted quaternary ammonium ethers. The bacterial removal was achieved due to the presence of cationic monomers on clay surface [47]. The existence of monomer enhanced the composite with positive charges, that electrostatically attracted the negative phospholipids of the bacterial cell membrane causing cell disruption. Thus, CPNs are more efficient than polymers alone for bacterial removals. Also, chitosan-based NCs are known to have an antimicrobial activity. Interestingly, montmorillonite-chitosan NCs was more efficient for the removal of S. aureus and E. coli than montmorillonite and chitosan alone [49]. Additionally, bentonite silver and zinc oxide NCs were examined for bacterial removal via adhesion and killing mechanism [50]. Furthermore, E. coli was removed via NCs of rectorite modified with PVA, chitosan, and sodium-dodecylsulfonate compared to the single components [46,51]. High antimicrobial activity was also reached via chitosan-organoclay and chitosan-montmorillonite modified with $\mathrm{Ag}^{+}$nanoparticles [52,53].

Generally, the microbial removals using CPNs is controlled by various factors such as the properties of the adsorbent (surface charge, composition, etc.), the characteristics of the bacterial strains and the operating conditions ( $\mathrm{pH}$, temperature, dosage, etc.). In this context, most chitosan NCs showed antibacterial activity in acidic medium but, $\mathrm{N}-(2-$ hydroxyl)propyl-3-trimethyl ammonium chitosan $\mathrm{Cl}$ displayed antibacterial activity in a large range of $\mathrm{pH}[46,54,55]$. Finally, the reuse of any CPNs is very important due to the cost of application. As reported in the literature, the reuse of CPNs applied for microbial removal was achieved using various reagents such as $\mathrm{NaClO}, \mathrm{HCl}$, and steam $[47,56]$. As a result of their high antimicrobial activity, CPNs can be applied efficiently to disinfect contaminated water.

\subsection{Organic Pollutants Removal}

The presence of dangerous toxic organic pollutants (organic acids, phenols, pesticides, dyes, etc.) may cause environmental problems even at trace amounts. Interestingly, these organic contaminants were removed using $\mathrm{CPNs}$ as adsorbent, due to the existence of polymeric hydrophobic parts on the NCs surfaces [57-90]. In this perspective, several $\mathrm{CPNs}$ in the form of powder or tablets were prepared using the thin-coated layer methods. These methods provide an enhancement of the adsorbent reusability after adsorption of toxic contaminants [57]. As listed in Table 2, different organic contaminants can be removed from water via adsorption process using CPNs. 
Table 2. Removal of different organic contaminants from water using clay-polymers nanocomposites (CPNs) adsorbents.

\begin{tabular}{|c|c|c|c|c|c|c|c|}
\hline Adsorbent & Adsorbate & $\begin{array}{l}\text { Temp. } \\
\left({ }^{\circ} \mathrm{C}\right)\end{array}$ & $\mathrm{pH}$ & $\begin{array}{c}\text { Removal } \\
\text { Efficiency (\%) or } \\
\text { Adsorption } \\
\text { Capacity (mg/g) } \\
\end{array}$ & $\begin{array}{l}\text { Isotherm } \\
\text { Model }\end{array}$ & $\begin{array}{l}\text { Kinetics } \\
\text { Model }\end{array}$ & Ref. \\
\hline Chitosan-coated attapulgite & Tannic acid & - & 5.5 & $95.2 \mathrm{mg} / \mathrm{g}$ & Freundlich & $\begin{array}{l}\text { Pseudo-second } \\
\text { order }\end{array}$ & [58] \\
\hline $\begin{array}{l}\text { palygorskite/chitosan resin } \\
\text { microspheres }\end{array}$ & Tannic acid & - & 8.0 & $455.0 \mathrm{mg} / \mathrm{g}$ & Langmuir & $\begin{array}{l}\text { Pseudo-second } \\
\text { order }\end{array}$ & [59] \\
\hline Chitosan/bentonite & Tartrazine & 47 & 2.5 & $294.1 \mathrm{mg} / \mathrm{g}$ & Langmuir & $\begin{array}{l}\text { Pseudo-second } \\
\text { order }\end{array}$ & [66] \\
\hline $\begin{array}{l}\text { Chitosan-g-poly (acrylic } \\
\text { acid)/montmorillonite }\end{array}$ & $\begin{array}{l}\text { Methylene } \\
\text { blue }\end{array}$ & - & 6.5 & $1895.0 \mathrm{mg} / \mathrm{g}$ & Langmuir & $\begin{array}{l}\text { Pseudo-second } \\
\text { order }\end{array}$ & [72] \\
\hline Chitosan/montmorillonite & Congo red & 30 & 4.0 & - & Langmuir & $\begin{array}{l}\text { Pseudo-second } \\
\text { order }\end{array}$ & [73] \\
\hline $\begin{array}{l}\text { Amino-modified } \\
\text { polyacrylamide-bentonite NCs }\end{array}$ & $\begin{array}{l}\text { Malachite } \\
\text { green }\end{array}$ & 30 & 6.0 & $656.5 \mathrm{mg} / \mathrm{g}$ & Freundlich & $\begin{array}{l}\text { Pseudo-second } \\
\text { order }\end{array}$ & [78] \\
\hline $\begin{array}{c}\text { Mixture of bentonite, acrylic } \\
\text { polymer, and } \\
\text { polyethylene-diamine } \\
\text { (Zwitterionic adsorbent) }\end{array}$ & $\begin{array}{l}\text { Acid Red and } \\
\text { Brilliant Green }\end{array}$ & 27 & - & $\begin{array}{c}70.09 \text { and } 255.99 \\
\mathrm{mg} / \mathrm{g}\end{array}$ & - & - & [79] \\
\hline $\begin{array}{c}\text { AAm-AMPSNa/clay hydrogel } \\
\text { nanocomposite and acrylamide } \\
\text { (AAm)-2-acrylamide-2- } \\
\text { methylpropanesulfonic acid } \\
\text { sodium salt (AMPSNa) } \\
\text { hydrogel }\end{array}$ & $\begin{array}{l}\text { Brilliant cresyl } \\
\text { blue and } \\
\text { Safranine-T }\end{array}$ & 25 & - & $\begin{array}{c}494.2 \text { and } 484.2 \\
\mathrm{mg} / \mathrm{g}\end{array}$ & Langmuir & $\begin{array}{l}\text { Pseudo-second } \\
\text { order }\end{array}$ & [80] \\
\hline Humic acid-modified bentonite & $\begin{array}{c}2,4- \\
\text { dichlorophenol }\end{array}$ & 30 & 6.5 & $14.23 \mathrm{mg} / \mathrm{g}$ & - & - & [81] \\
\hline $\begin{array}{l}\text { montmorillonite/layer double } \\
\text { hydroxide }\end{array}$ & Methyl orange & - & - & $88 \%$ & - & - & [82] \\
\hline $\begin{array}{l}\text { montmorillonite /layer double } \\
\text { hydroxide }\end{array}$ & $\begin{array}{l}\text { Methylene } \\
\text { blue }\end{array}$ & - & - & $74 \%$ & - & - & [82] \\
\hline Chitosan/bentonite & $\begin{array}{l}\text { Amido Black } \\
\text { 10B }\end{array}$ & 20 & 2.0 & $323.6 \mathrm{mg} / \mathrm{g}$ & Langmuir & $\begin{array}{l}\text { Pseudo-second } \\
\text { order }\end{array}$ & [83] \\
\hline $\begin{array}{c}\text { Hydrogels of } \\
\text { Kappa-carrageenan-g- } \\
\text { poly(acrylamide)/sepiolite } \\
\text { NCs }\end{array}$ & Crystal violet & $\begin{array}{l}\text { Ambient } \\
\text { Temp. }\end{array}$ & 10.0 & $47.0 \mathrm{mg} / \mathrm{g}$ & Langmuir & $\begin{array}{l}\text { Pseudo-second } \\
\text { order }\end{array}$ & [84] \\
\hline $\begin{array}{c}\text { Poly(acrylic } \\
\text { acid-co-2-acrylamido-2- } \\
\text { methylpropanesulfonic acid)/ } \\
\text { montmorillonite }\end{array}$ & $\begin{array}{l}\text { Methylene } \\
\text { blue }\end{array}$ & 25 & 10.0 & $215.0 \mathrm{mg} / \mathrm{g}$ & $\begin{array}{l}\text { Redlich- } \\
\text { Peterson }\end{array}$ & $\begin{array}{l}\text { Pseudo-second } \\
\text { order }\end{array}$ & [85] \\
\hline $\begin{array}{c}\text { Alginate-clay quasi-cryogel } \\
\text { beads }\end{array}$ & $\begin{array}{l}\text { Methylene } \\
\text { blue }\end{array}$ & 40 & - & $181.8 \mathrm{mg} / \mathrm{g}$ & Langmuir & $\begin{array}{l}\text { Pseudo-second } \\
\text { order }\end{array}$ & [86] \\
\hline Chitosan/bentonite & $\begin{array}{l}\text { Malachite } \\
\text { green }\end{array}$ & 37 & 6.0 & $435.0 \mathrm{mg} / \mathrm{g}$ & Langmuir & $\begin{array}{l}\text { Pseudo-second } \\
\text { order }\end{array}$ & [87] \\
\hline $\begin{array}{l}\text { polyaniline /montmorillonite } \\
\text { clay nanocomposites }\end{array}$ & Green 25 & 20 & 6.0 & $100 \%$ & Langmuir & $\begin{array}{l}\text { Pseudo-second } \\
\text { order }\end{array}$ & [88] \\
\hline $\begin{array}{l}\text { Tetraethoxysilane- } \\
\text { functionalized Na-bentonite ( } 2 \\
\mathrm{wt} \%) \text { incorporated into } \\
\text { polysulfone/polyethylenimine } \\
\text { membranes }\end{array}$ & $\begin{array}{l}\text { Methylene } \\
\text { blue }\end{array}$ & $\begin{array}{l}\text { Room } \\
\text { Temp. }\end{array}$ & - & $98.9 \%$ & - & - & [89] \\
\hline $\begin{array}{l}\text { carboxy methyl cellulose/ } \\
\text { nano-organobentonites }\end{array}$ & Nine pesticides & - & - & $57-100 \%$ & - & - & [89] \\
\hline
\end{tabular}




\subsubsection{Phenol, Tannic Acid and Pesticides Removal}

The direct release of organic pollutants in water greatly affects the environment. Among these organics, polyphenolic tannic acid, which resulted from decomposed organic materials, is highly harmful for organisms in aquatic environment. Commonly, tannic acid compounds exist in surface water and soil. Consequently, it is important to find the proper way for their removal. In this context, attapulgite clay coated with chitosan was used as a new adsorbent for tannic acid removal with an adsorption capacity of $95.3 \mathrm{mg} / \mathrm{g}$. This adsorption resulted from Van der Waals attractions, H-bonding, and electrostatic interactions [58]. Interestingly, this nanocomposite was improved to adsorb more tannic acid $(456 \mathrm{mg} / \mathrm{g})$ using solid matrix of protonated palygorskite clay $(20 \% \mathrm{wt} / \mathrm{wt})$ with chitosan resin microspheres [59]. In this study, the reusability of this novel nanocomposite was studied using hydrochloric acid $(0.1 \mathrm{M})$ as an eluent up to three cycles showing a significant decrease of the adsorption capacity ( $58 \mathrm{mg} / \mathrm{g}$ ) of tannic acid [59].

Similarly, phenolic materials such as 4-chlorophenol and phenols were removed using alginate polymer support incorporated by clay modified with a surfactant hexadecyl trimethyl ammonium. This adsorbent allowed a removal capacity of $0.119 \mathrm{mg} / \mathrm{g}$ and $0.335 \mathrm{mg} / \mathrm{g}$ respectively for 4-chlorophenol and phenols [60]. Also, trichlorophenol and trinitrophenol were removed using nano- montmorillonite synthesized from poly4 -vinylpyridine-co-styrene with removal efficiency of $60 \%$ and $99.6 \%$, respectively. In this study, it has been suggested that a weak Van der Waals interaction is involved in the adsorption mechanism [61]. In another study, phenolic materials were removed by nanocomposite prepared using cetyltrimethylammonium poly(diallyldimethylammonium) to modify montmorillonite clay. Although the surfactant was not correctly intercalated inside the clay montmorillonite, the adsorption capacity toward phenols was enhanced [62].

Wastewater was also treated to remove pesticides like 2,4-dichlorophenol and atrazine using CPNs as adsorbents. $90 \%$ poly-4-vinylpyridine-co-styrene was used to modify montmorillonite allowing the removal of $99 \%$ of atrazine within only $40 \mathrm{~min}$ [63]. Interestingly, the synthesized NCs decreased the presence of pesticide to $3 \mu \mathrm{g} / \mathrm{L}$ during the use of fixed bed experiment. However, the adsorption capacity of these NCs was decreased in the presence of other organic soluble contaminants due to the competition occurred on the adsorbent surface. In another study, dinitrophenols were removed using membranes filled with NCs of organo- montmorillonite/ polyethersulfone. The NCs were prepared using wet-phase inversion and solution dispersion methods [64]. The addition of $4 \%$ of organomontmorillonite enhanced the nitrophenols removal. Nitrophenols were removed via hydrogen bonding over NCs surfaces at $\mathrm{pH}$ 4.6. Furthermore, more than 70\% of mecoprop and clopyralid anionic pesticides was removed over hexadimethrine/ montmorillonite $\mathrm{NCs}$ due to electrostatic interactions with adsorbent $\mathrm{NH}^{4+}$ groups [65].

\subsubsection{Dyes Removal}

The dyes removal from water/wastewater using clay/polymers nanocomposites was reported by many studies. In this context, many researchers reported the use of chitosan polymer [66-73]. For example, clay-polymer nanocomposite of chitosan/bentonite was synthesized and tested for the removal of azo dye tetrazine, known by its harmful effect on aquatic organisms [66]. According to this study, the $\mathrm{pH}$ value is the driving force of the adsorption process. At low $\mathrm{pH}$, the +ve charge was produced allowing the electrostatic attractions between dye and nanocomposite surfaces. However, at higher $\mathrm{pH}$ value, the charge became -ve reducing the adsorption process due to the repulsion forces between NCs surfaces and the dye. The cross-linked chitosan in the nanocomposite with epichlorohydrin becomes water insoluble improving the adsorption process. Also, methylene blue (MB) dye was removed using chitosan/clay magnetic beads at $\mathrm{pH}$ 3-12 with weight ratio of clay to chitosan of more than 0.5 . These magnetic NCs provided faster removal of MB within $13 \mathrm{~min}(50 \%$ removal efficiency and $83 \mathrm{mg} / \mathrm{g}$ maximum adsorption capacity) [67]. The adsorption process occurred via a mechanism of electrostatic attractions between clay -ve charge and dye +ve charge for wide $\mathrm{pH}$ range. Similarly, 
chitosan-clay NCs were used for the removal of Rhodamin-6 G with adsorption capacity of $446.43 \mathrm{mg} / \mathrm{g}$ [68]. At high $\mathrm{pH}$, the adsorption of this positively charged dye occurred due to the attraction with the negatively charged adsorbent. The pseudo-second-order model was found to explain the adsorption kinetics of Rhodamin-6 G [68]. In the same way, high removal efficiency $(99.99 \%)$ was obtained for MB using chitin-clay NCs with an adsorption capacity of $152.3 \mathrm{mg} / \mathrm{g}$. The adsorption was greatly linked to the $\mathrm{pH}$ and followed the Langmuir isotherm [69]. Chitosan modified nano-organoclay was also applied for the removal of reactive red-141 (adsorption capacity of $440 \mathrm{mg} / \mathrm{g}$ ) and reactive blue-21 (adsorption capacity of $477 \mathrm{mg} / \mathrm{g}$ ). The adsorption data of the two dyes followed pseudosecond-order model [70]. For reactive dye (Yellow 3 RS), the adsorption capacity reached $71.39 \mathrm{mg} / \mathrm{g}$ over chitosan modified palygorskite clay NCs, which is significantly higher than that obtained with unmodified clay materials. $(6.4 \mathrm{mg} / \mathrm{g})$ [71]. At high $\mathrm{pH}$, the adsorption was decreased due to the repulsion forces between similar charges while at low $\mathrm{pH}$ the positive charge was formed over chitosan surface due to the existence of amino groups allowing the adsorption via electrostatic attractions [71].

Other polymer types were used to formulate PNCs useful for dyes removal [74-78]. For example, reactive yellow K-4G, and disperse yellow-brown S-2RFL were removed via NCs of poly(epicholorohydrin-dimethylamine) and bentonite with maximum adsorption capacity of $30.9 \mathrm{mg} / \mathrm{g}$ and $12.5 \mathrm{mg} / \mathrm{g}$, respectively. The complete dyes removal was reached via the optimization of polymers quantity [74]. Using the same approach, humic acid immobilized-amine-modified bentonite-polyacrylamide nanocomposite was tested for the removal of various dyes (malachite green, MB, and crystal violet) from wastewater [76]. This clay-polymer nanocomposite showed maximum adsorption capacity of malachite green, MB, and crystal violet of 658,649 , and $511 \mu \mathrm{mol} / \mathrm{g}$, respectively at $\mathrm{pH} 4.8$. In This study, intraparticle diffusion mechanism was suggested [76].

Recently, De Sousa et al. synthesized hybrid clay-polymer nanocomposite using sodium bentonite and ureasil-poly(ethylene oxide) via sol gel method for the removal of $\mathrm{MB}$ from water. Interestingly, $\mathrm{MB}$ was removed rapidly and efficiently through the adsorption process [77]. In another work, $\mathrm{MB}$ was removed from water using hybrid membranes based on kaolin and polystyrene. These membranes were fired at $1000{ }^{\circ} \mathrm{C}$ allowing the modification of polystyrene and the formation of cavities inside the clay matrix. The resulted materials have porous structure with expanded surface area. An optimum removal of MB from water was obtained with clay membrane loaded with $20 \%$ $(w t / w t)$ polystyrene [78]. The mechanism of MB removal over clay-polymer composites was described in the literature [31] as shown in Figure 2.

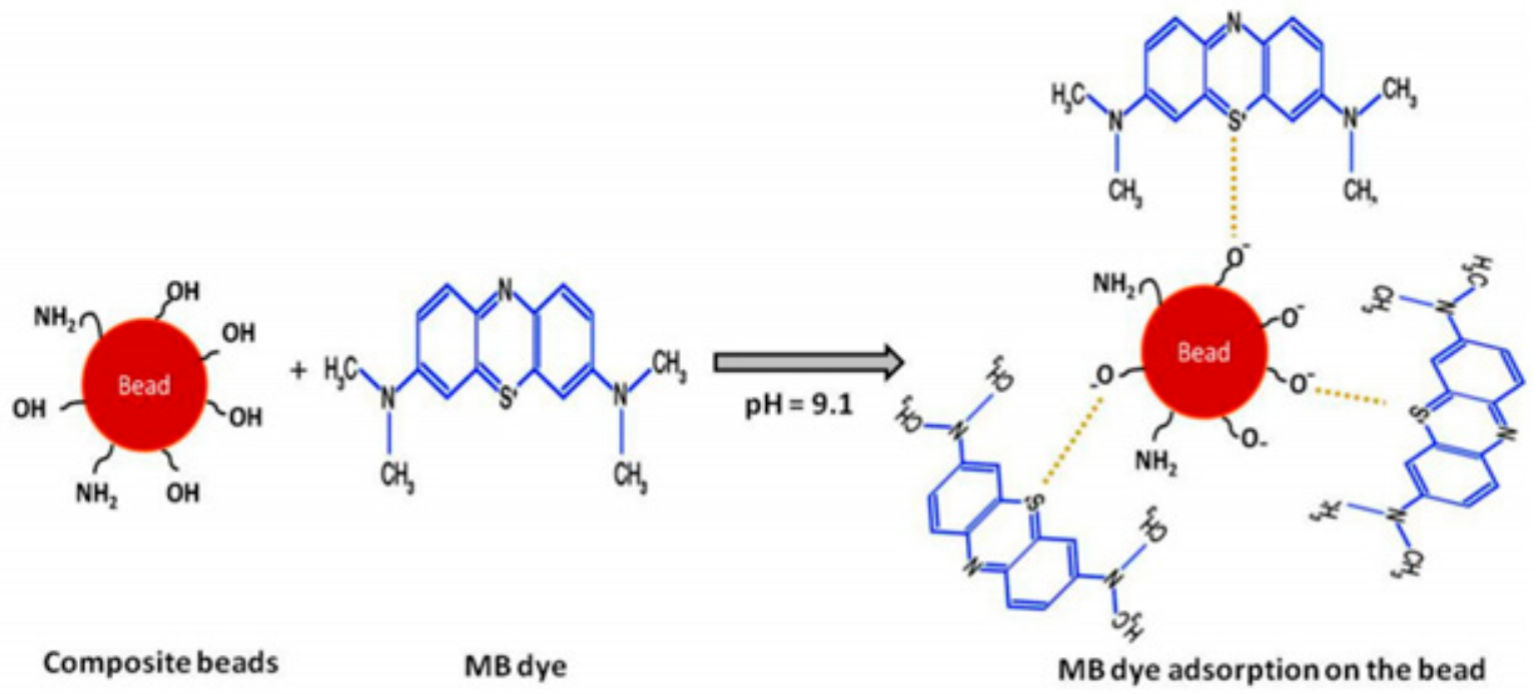

Figure 2. The mechanism of methylene blue (MB) removal over clay-polymer composite [31]. 
Generally, dyes removal efficiency offered by the new CPNs varied depending on the polymerization process and the used raw materials. For each dye, the adsorption performance (removal rates and the adsorption capacity) varied from one experiment to another depending on the $\mathrm{CPNs}$ nature and operating conditions (dosage, $\mathrm{pH}$, temperature, contact time, dye type, initial dye concentration, etc.).

\subsection{Inorganic Pollutants Removal}

\subsubsection{Toxic Gases Removal}

Clay-polymer nanocomposites can be used for the adsorption of toxic gases like ammonia and metallic gases such as mercury $\mathrm{Hg}^{0}$. For example, chitosan-bentonite composite was used as adsorbent for the elimination of $\mathrm{Hg}^{0}$. In this study, the authors found that the low surface area of composite compared to single bentonite caused less removal of $\mathrm{Hg}^{0}$ [91] Also, a composite, synthesized from acid-activated bentonite and natural palygorskite via polymerization reaction between $N, N^{\prime}$-methylenebisacrylamide and acrylic acid, was used for the adsorption of ammonia [92]. To increase the ability to remove ammonia, Lewis acid-base interaction was used to bind copper divalent ions with the composite. Among all acid-treated bentonite/acrylic acid polymer composites, $66 \%$ acid-treated bentonite exhibited the highest adsorption capacity. However, $75 \%$ palygorskite showed the maximum adsorption capacity among all palygorskite/acrylic acid polymer nanocomposites. The differences in adsorption capacity between acid-treated bentonite/acrylic acid polymer and palygorskite composites are related to the existence of mesopores (diameters between 2 and $50 \mathrm{~nm}$ ) in the composite (copper-complexed clay/poly-acrylic acid composite), that allowed the interaction between polymers active sites and ammonia [92].

\subsubsection{Metalloids and Heavy Metals Removal}

Urbanization, fertilizer application, and rapid industrialization are the major sources of water toxic metalloids and heavy metals such as $\mathrm{As}, \mathrm{U}, \mathrm{Se}, \mathrm{Sb}, \mathrm{Cr}, \mathrm{Cd}, \mathrm{Ni}, \mathrm{Pb}$, and $\mathrm{Cu}$. Metalloids and heavy metals represent a serious danger for human and living organisms. These pollutants can be accumulated inside different organisms causing harmful effects. Therefore, their removal from water is essential for healthy environment [93].

Efforts have been conducted to remove the toxic heavy metals from water using clay as the support and chitosan as the polymer [94-111]. Divalent copper ions were removed from water using chitosan-silver NPs clay composite with a maximum adsorption capacity $(181.6 \mathrm{mg} / \mathrm{g})$ at $\mathrm{pH} 7$ [94]. The high adsorption at $\mathrm{pH} 7$ resulted from the interaction between chitosan functional groups and $\mathrm{Cu}(\mathrm{II})$ ions. At high $\mathrm{pH}$, the formed cupric hydroxide decreased the adsorption process of copper ions. Another nanocomposite, poly-methacrylic acid grafted chitosan-bentonite, was tested for the removal of Cd (II), $\mathrm{Pb}$ (II), and $\mathrm{Hg}$ (II) ions. In this case, removal values of $78 \%, 89 \%$, and $94 \%$, respectively for $\mathrm{Cd}$ (II), $\mathrm{Pb}$ (II), and $\mathrm{Hg}$ (II) were obtained at high $\mathrm{pH}$ [95]. For the same purpose, chitosan/attapulgite composites were synthesized and tested for the removal of $\mathrm{Cr}$ (III) and Fe(III) from aqueous solution. The maximum adsorption capacity was 11.65 and $10.41 \mathrm{mg} / \mathrm{g}$ for $\mathrm{Cr}(\mathrm{III})$ and $\mathrm{Fe}(\mathrm{III})$, respectively. These values were obtained with adsorbent dosage of $0.2 \mathrm{~g} / \mathrm{l}$. However, the adsorption efficiency was found to be increased by increasing the temperature. Generally, the metal sorption is controlled by the process of electrons sharing between adsorbent and metals or through the covalent bonding [96].

In the same context, Chitosan-Al-pillared montmorillonite nanocomposite was used to remove $\mathrm{Cr}(\mathrm{VI})$ with an adsorption capacity of $15.68 \mathrm{mg} / \mathrm{g}$ [97]. Lead and copper divalent ions were removed with a similar nanocomposite prepared with clay: chitosan ratio of 1:0.45 to remove $\mathrm{Pb}$ (II) and $\mathrm{Cu}$ (II) at $\mathrm{pH} 6.5$ with an efficiency of $99.5 \%$ and $96 \%$, respectively via chemisorption mechanism. This nanocomposite when treated with nitric acid showed excellent reuse results [98]. Also, clay-polymer nanocomposite was successfully synthesized using chitosan and fibrous clay minerals like palygorskite. Different mass ratios of palygorskite to chitosan (1:1, 2:1, and 1:2) was prepared and applied for the removal of $\mathrm{Pb}$ (II) from water. A maximum removal capacity $(201.5 \mathrm{mg} / \mathrm{g})$ was obtained 
using the ratio 1:1 [99]. The availability of pores equally from both clay and polymer is the reason for high removal of $\mathrm{Pb}$ (II). In another study, the lead adsorption was increased by many folds from aqueous solution when the clay mass increased by $10 \%$ with respect to the polymer polystyrene inside the composite [100]. In a recent research, high amount of lead ions were removed using ion-imprinted polymer/ montmorillonite NCs [101].

For the same purpose, chitosan-grafted polyacrylic acid bentonite was used to remove various metals (Ni (II), $\mathrm{Cd}$ (II), $\mathrm{Zn}$ (II), and $\mathrm{Cu}$ (II)) from water. Maximum removal was obtained at $\mathrm{pH}$ of 8, 6, 7, and 6, respectively for $\mathrm{Ni}$ (II), Cd (II), Zn (II), and Cu (II) [102]. The maximum adsorption at high $\mathrm{pH}$ can be explained by the existence of negative charge over the adsorbent surfaces allowing the chelation of positive heavy metals. Similarly, chemisorption mechanism explained the efficient metal removal (Ni (II), $\mathrm{Cu}(\mathrm{II})$, and $\mathrm{Pb}(\mathrm{II})$ ) from aqueous solution by chitosan immobilized on bentonite using ethylene glycol diglycidyl ether as a cross-linker [103]. This adsorbent offered high adsorption capacity of 15.82, 21.55, and $26.38 \mathrm{mg} / \mathrm{g}$ respectively for $\mathrm{Ni}$ (II), $\mathrm{Cu}$ (II), and $\mathrm{Pb}$ (II) [104]. An exothermic adsorption was observed for these metals as concluded from the thermodynamic parameters with the decreasing of the entropy behavior [105-110]. Additionally, adsorption of $\mathrm{Cu}$ (II) was spontaneous only at $25^{\circ} \mathrm{C}$, while that of $\mathrm{Pb}$ (II) was always spontaneous. Concerning Ni (II), the adsorption was non-spontaneous at $25-55{ }^{\circ} \mathrm{C}$ [104]. In the same work, the desorption process was studied showing high recovery of $\mathrm{Cu}$ (II) (92\%) obtained with $\mathrm{HCl}$ solution ( $\mathrm{pH}$ 1) and under agitation (2 h) [104] Remarkably, the effectiveness of membrane of chitosan-kaolin-based ceramic synthesized using PVA as the chelating material for the removal of $\mathrm{Hg}$ and $\mathrm{As}$ from aqueous solution was also demonstrated [111].

The interesting opportunity offered by the implication of chitosan in the adsorption was well performed. The mechanism of heavy metals removal over chitosan-clay nanocomposite was described in the literature [31] as shown in Figure 3.

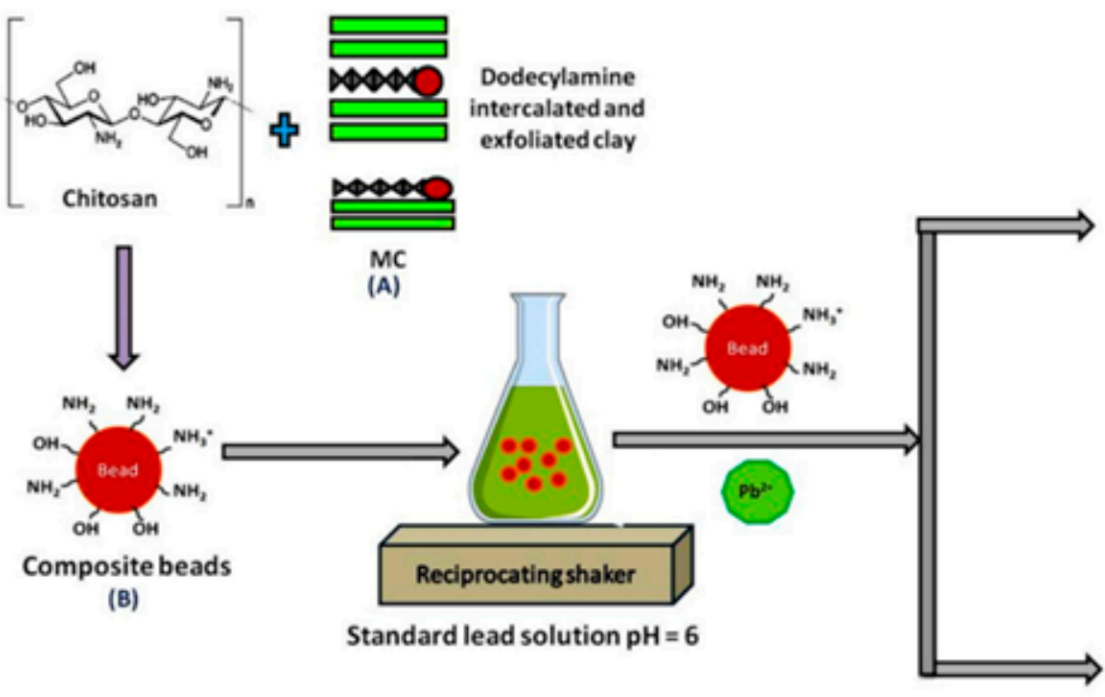

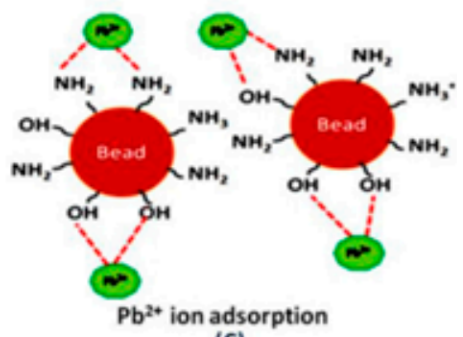

(C)

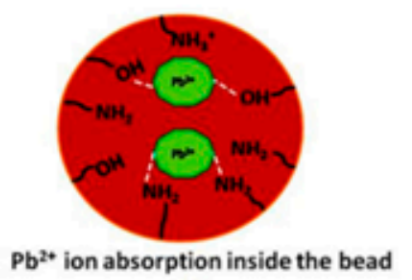

(D)

Figure 3. The mechanism of $\mathrm{Pb}^{+2}$ ions removal over chitosan-clay composite [31].

On the other hand, various clay NCs involving other types of polymers were tested for the removal of metals. For example, montmorillonite modified with $N$-methyl- $D$ glucamine-based monomer through radical polymerization reaction to form water soluble nanocomposite was used with ion-exchange resin for the removal of As [112]. Interestingly, the resin removed $56 \mathrm{mg} / \mathrm{g}$ of arsenic via a Langmuir adsorption isotherm and decreased its level below the allowed limits according to the World Health Organization (WHO). Recently, in situ polymerization was used for the preparation of magnetic clay 
-polymer nanocomposite by using monomer methyl methacrylate, iron oxide nanoparticles, and bentonite [113]. This magnetic nanocomposite adsorbed $113 \mathrm{mg} / \mathrm{g}$ of Cr (VI) from water. Intraparticle diffusion equation was used to approve that the adsorption process was reached via film-diffusion. Another strategy was developed by Ravikumar and Udayakumar et al. 2020 using M. oleivera biopolymer and bentonite (mass ration 1:1) to produce green nanocomposite by the solution processing method. The application of this nanocomposite for the removal of $\mathrm{Cd}$ (II), $\mathrm{Cr}$ (II), and $\mathrm{Pb}$ (II) from aqueous solution via coagulo-adsorption process showed an average removal efficiency of heavy metals of $99.99 \%$ at $\mathrm{pH} 6-8,2-4$, and 5-7 for $\mathrm{Cd}, \mathrm{Cr}$, and $\mathrm{Pb}$, respectively with a dosage of $5 \mathrm{~g} / \mathrm{L}$ [114].

The reported data showed various possibilities useful to remove the metal from water as summarized in Table 3. Nevertheless, in some cases, the water can be contaminated by the nanocomposite itself, which should be taken into consideration and studied in more details.

Table 3. Water treatment from different inorganic contaminants over clay-polymers nanocomposites (NCs) adsorbents.

\begin{tabular}{|c|c|c|c|c|c|c|c|}
\hline Adsorbent & Adsorbate & $\begin{array}{l}\text { Temp. } \\
\left({ }^{\circ} \mathrm{C}\right)\end{array}$ & $\mathrm{pH}$ & $\begin{array}{c}\text { Removal } \\
\text { Efficiency (\%) or } \\
\text { Adsorption } \\
\text { Capacity (mg/g) }\end{array}$ & $\begin{array}{l}\text { Isotherm } \\
\text { Model }\end{array}$ & $\begin{array}{l}\text { Kinetics } \\
\text { Model }\end{array}$ & Ref. \\
\hline Bentonite/humic acid & $\mathrm{Cu}(\mathrm{II})$ & 30 & 6.50 & $22.41 \mathrm{mg} / \mathrm{g}$ & - & - & [81] \\
\hline Chitosan/attapulgite & $\mathrm{Cr}$ (III) & 45 & 5.0 & $65.37 \mathrm{mg} / \mathrm{g}$ & Langmuir & $\begin{array}{l}\text { Intraparticle } \\
\text { diffusion }\end{array}$ & [96] \\
\hline $\begin{array}{l}\text { chitosan grafted poly acrylic } \\
\text { acid bentonite composites }\end{array}$ & Cd (II) & 25 & 6.0 & $51.60 \mathrm{mg} / \mathrm{g}$ & Langmuir & - & [96] \\
\hline Chitosan/attapulgite & Fe (III) & 45 & 3.0 & $62.51 \mathrm{mg} / \mathrm{g}$ & Langmuir & $\begin{array}{l}\text { Intraparticle } \\
\text { diffusion }\end{array}$ & [96] \\
\hline $\begin{array}{l}\text { Chitosan-Al-pillared MMT } \\
\text { nanocomposite }\end{array}$ & $\mathrm{Cr}(\mathrm{VI})$ & 25 & 6.38 & $15.68 \mathrm{mg} / \mathrm{g}$ & Langmuir & $\begin{array}{l}\text { Pseudo-second } \\
\text { order }\end{array}$ & [97] \\
\hline $\begin{array}{l}\text { Chitosan-Al-pillared } \\
\text { montmorillonite NCs }\end{array}$ & $\mathrm{Pb}$ (II) & 25 & 6.5 & $99.6 \%$ & Freundlich & $\begin{array}{l}\text { Pseudo-second } \\
\text { order }\end{array}$ & [98] \\
\hline $\begin{array}{l}\text { Chitosan grafted poly acrylic } \\
\text { acid bentonite composites }\end{array}$ & $\mathrm{Ni}(\mathrm{II})$ & 25 & 7.0 & $49 \mathrm{mg} / \mathrm{g}$ & Langmuir & - & [102] \\
\hline $\begin{array}{l}\text { Chitosan grafted poly acrylic } \\
\text { acid bentonite composites }\end{array}$ & $\mathrm{Cu}$ (II) & 25 & 6.0 & $88.60 \mathrm{mg} / \mathrm{g}$ & Langmuir & - & [102] \\
\hline $\begin{array}{l}\text { Chitosan immobilized on } \\
\text { bentonite }\end{array}$ & $\mathrm{Pb}$ (II) & 35 & - & $26.39 \mathrm{mg} / \mathrm{g}$ & Freundlich & $\begin{array}{l}\text { Pseudo-second } \\
\text { order }\end{array}$ & [104] \\
\hline Polyaniline modified bentonite & $\mathrm{U}(\mathrm{VI})$ & 20 & 6.5 & $14.10 \mathrm{mg} / \mathrm{g}$ & Langmuir & $\begin{array}{l}\text { Pseudo-second } \\
\text { order }\end{array}$ & [115] \\
\hline $\begin{array}{l}\text { Bentonite/thiourea- } \\
\text { formaldehyde } \\
\text { composite }\end{array}$ & Mn (VII) & - & 4.0 & $14.82 \mathrm{mg} / \mathrm{g}$ & Langmuir & $\begin{array}{l}\text { Pseudo-second } \\
\text { order }\end{array}$ & [116] \\
\hline $\begin{array}{l}\text { Alginate-montmorillonite } \\
\text { nanocomposite }\end{array}$ & $\mathrm{Pb}(\mathrm{II})$ & - & 6.0 & $244.7 \mathrm{mg} / \mathrm{g}$ & - & - & [117] \\
\hline $\begin{array}{l}\text { Alginate-montmorillonite } \\
\text { nanocomposite }\end{array}$ & $\begin{array}{l}\mathrm{Mn}(\mathrm{II}), \mathrm{Fe}(\mathrm{III}) \\
\mathrm{Ni}(\mathrm{II}), \mathrm{Zn}(\mathrm{II})\end{array}$ & - & 6.0 & $100 \%$ & - & - & [117] \\
\hline $\begin{array}{l}\text { Chitin/bentonite } \\
\text { nanocomposite }\end{array}$ & $\mathrm{Cr}(\mathrm{VI})$ & - & 4.0 & $443.72 \mathrm{mg} / \mathrm{g}$ & Freundlich & - & [118] \\
\hline Na-montmorillonite / cellulose & $\mathrm{Cr}(\mathrm{VI})$ & - & $3.8-5.5$ & $22.3 \mathrm{mg} / \mathrm{g}$ & Langmuir & $\begin{array}{l}\text { Pseudo-second } \\
\text { order }\end{array}$ & {$[119]$} \\
\hline $\begin{array}{c}\text { Chitosan/PVA/bentonite } \\
\text { nanocomposite }\end{array}$ & $\mathrm{Hg}(\mathrm{II})$ & - & - & $360.74 \mathrm{mg} / \mathrm{g}$ & - & - & {$[120]$} \\
\hline Chitosan and montmorillonite & Se (VI) & - & - & $18.50 \mathrm{mg} / \mathrm{g}$ & - & - & {$[121]$} \\
\hline $\begin{array}{l}\text { Poly(methacrylic acid) grafted } \\
\text { chitosan/bentonite grafted } \\
\text { chitosan / bentonite }\end{array}$ & Th (IV) & 30 & 5.0 & $110.60 \mathrm{mg} / \mathrm{g}$ & Langmuir & $\begin{array}{l}\text { Pseudo-second } \\
\text { order }\end{array}$ & [122] \\
\hline
\end{tabular}


Table 3. Cont.

\begin{tabular}{|c|c|c|c|c|c|c|c|}
\hline Adsorbent & Adsorbate & $\begin{array}{l}\text { Temp. } \\
\left({ }^{\circ} \mathrm{C}\right)\end{array}$ & $\mathrm{pH}$ & $\begin{array}{c}\text { Removal } \\
\text { Efficiency (\%) or } \\
\text { Adsorption } \\
\text { Capacity (mg/g) }\end{array}$ & $\begin{array}{l}\text { Isotherm } \\
\text { Model }\end{array}$ & $\begin{array}{l}\text { Kinetics } \\
\text { Model }\end{array}$ & Ref. \\
\hline $\begin{array}{l}\text { L-cysteine modified } \\
\text { bentonite-cellulose } \\
\text { nanocomposite }\end{array}$ & $\mathrm{Cu}(\mathrm{II})$ & 50 & - & $32.37 \mathrm{mg} / \mathrm{g}$ & Langmuir & $\begin{array}{l}\text { Pseudo-second } \\
\text { order }\end{array}$ & [123] \\
\hline $\begin{array}{l}\text { Poly(acrylic acid-co- } \\
\text { acrylamide)/attapulgite }\end{array}$ & $\mathrm{Cu}(\mathrm{II})$ & - & 6.0 & $69.76 \mathrm{mg} / \mathrm{g}$ & - & - & [124] \\
\hline $\begin{array}{l}\text { Cellulose-graft- polyacry- } \\
\text { lamide/hydroxyapatite }\end{array}$ & $\mathrm{Cu}(\mathrm{II})$ & - & 7.0 & $176.0 \mathrm{mg} / \mathrm{g}$ & - & $\begin{array}{l}\text { Pseudo-second } \\
\text { order }\end{array}$ & [125] \\
\hline Chitosan/clinoptilolite & $\mathrm{Ni}(\mathrm{II})$ & 25 & 5.0 & $247.04 \mathrm{mg} / \mathrm{g}$ & Langmuir & $\begin{array}{l}\text { Pseudo-second } \\
\text { order }\end{array}$ & {$[126]$} \\
\hline $\begin{array}{l}\text { Cystene-montmorillonite } \\
\text { nanocomposite }\end{array}$ & $\mathrm{Pb}(\mathrm{II})$ & - & - & $0.180 \mathrm{mg} / \mathrm{g}$ & - & - & {$[127]$} \\
\hline $\begin{array}{l}\text { Cloisite-polycaprolactone } \\
\text { nanocomposite }\end{array}$ & $\mathrm{Pb}(\mathrm{II})$ & - & - & $88 \%$ & - & - & {$[128]$} \\
\hline Attapulgite/poly(acrylic acid) & $\mathrm{Pb}(\mathrm{II})$ & - & 5.0 & $38.0 \mathrm{mg} / \mathrm{g}$ & Freundlich & $\begin{array}{l}\text { Pseudo-second } \\
\text { order }\end{array}$ & [129] \\
\hline
\end{tabular}

\section{Factors Making Clay-Polymers Nanocomposites Promising Materials for Wastewater Treatment}

This work reviews the most appropriate clay-polymers nanocomposites available for the treatment of water/wastewater containing different types of pollutants. Similar to other fields of fabricated hybrid composites, clay-polymers nanocomposites associate the advantages of their individual parts, like chemical stability, high surface charge, high surface structure, and mechanical stability as well as enhanced adsorption capacities to different pollutants that allow efficient water purification. Also, clay-polymers nanocomposites withstand the fixed bed systems high temperatures and pressures due to the improvement offered by polymers (thermal and the mechanical stability). Therefore, clay-polymers nanocomposites can be used in industrial scale with low exhaustion during long-term use [130]. Additionally, clay-polymers nanocomposites provide great price advantage compared to other famous adsorbents (zeolites, activated carbon, etc.) related to the use of both clay minerals and functional polymers. This cost advantage can be further enhanced with the reuse opportunity of the clay-polymers NCs that reduce the overall cost of treatment [131]. In addition to cost, clay-polymers nanocomposites can be applied at low dose allowing its potential use at industrial scale.

Generally, unmodified clay minerals such as montmorillonite, bentonite, and kaolinite showed poor adsorption capacity for many pollutants as reported by Styszko et al., (2015) [132]. However, several CPNs exhibit higher adsorption capacities than mineral clays. For example, $\mathrm{Cu}$ (II) ions were removed from water with adsorption capacity of $44.9 \mathrm{mg} / \mathrm{g}$ using natural mineral clay while this value was folded more than twice for CPNs [133]. Similarly, maximum adsorption capacity of dyes was found for clay composites. In this context, raw kaolinite and montmorillonite showed dye adsorption capacity of 29 and $19 \mathrm{mg} / \mathrm{g}$, respectively [134]. However, CPNs showed higher adsorption capacities as reported in Table 3 . In addition to that, mineral clays adsorb better in acidic solutions making their application difficult for the treatment of water/wastewater having neutral $\mathrm{pH}$ [132].

As reported in Tables 2 and 3, the pollutants removal efficiency allowed by synthesized CPNs varied depending on the polymerization process and the used raw materials. In some cases, the new nanocomposites exhibit an interesting removal capacity. For example, chitosan-g-poly (acrylic acid)/ montmorillonite showed an adsorption capacity of $1895.0 \mathrm{mg} / \mathrm{g}$ for methylene blue [72]. However, for poly(acrylic acid-co-2acrylamido-2- methylpropanesulfonic acid)/montmorillonite, the adsorption capacity was 
only $215.0 \mathrm{mg} / \mathrm{g}$ for the same dye [85]. Result variability was also observed for other pollutants (heavy metals, bacteria, etc.). Therefore, the removal rates and the adsorption capacities varied depending on the CPNs nature and on the operating conditions (dosage, pollutants, $\mathrm{pH}$, temperature, contact time, etc.). Many of these adsorbents have the ability to reduce the level of biological pollutants to the safe limits considered by WHO.

An additional advantage of clay polymer nanocomposites is their ability to be used in batch and fixed bed systems. When comparing both systems (batch and fixed bed), fixed bed system is most efficient for the continuous removal of contaminants and offered larger regeneration capacity of the adsorbent. Therefore, nanocomposites can be easily separated from reaction medium than unmodified mineral clays. This makes clay polymer nanocomposites more cost effective than other conventional adsorbents [135]. Moreover, clay polymer nanocomposites are more stable in water compared to their individual parts.

The advantages of clay polymer nanocomposites can be summarized in the economic cost, the improved performances, and the easy synthesis in large quantities. Therefore, more researches are needed to produce the most promising clay polymer nanocomposites and evaluate the process efficiency at large scale for the removal of different contaminants (biological, organic, and inorganic) from water/wastewater. Furthermore, the future research of clay polymer nanocomposites can include the development of clay polymer NCs membranes. Membranes will provide effective treatment with low- cost embedded adsorbents. Also, study should be addressed to the synthesis of clay polymer NCs hydrogels, which may be considered more attractive for water/wastewater treatment due to their high capacity and ease of regeneration. Hydrogels are usually excluded from water purification due to poor strength and poor mechanical properties that can be overcome via the synthesis of clay polymers NCs hydrogels. Additionally, it will be promising to fabricate multi-functional clay polymer NCs having the ability to adsorb simultaneously different types of cationic and anionic contaminants.

\section{Conclusions}

This review article summarizes the different types of clay polymer nanocomposites and their effective use for the removal of pollutants from water/wastewater. The introduction of CPNs is induced by the advantages offered by clay minerals such as their cheapness, availability, and valuable properties. Therefore, the combination of clay minerals and polymers as promising reinforcements produce nanocomposites of clay-polymers with advanced properties (high capacity, simple synthesis, eco-friendly, cost advantages, etc.) useful for pollutants removal. CPNs may include various polymers in their fabrication such as chitosan, polystyrene, polypropylene, polyesters, polyurethanes, epoxies, and polyvinyl chloride, using appropriate synthesis techniques. Interestingly, the developed CPNs showed significant advantages of established adsorbents for water/wastewater treatment. The current literatures reported the removal of different pollutants (bacteria, metals, phenol, tannic acid, pesticides, dyes, etc.) using clay polymers nanocomposites showing them as promising materials for water/wastewater treatment. However, the majority of results were collected based on research experiments conducted for pollutants in aqueous solutions at laboratory scale. Therefore, further investigations are needed to evaluate the process efficiency using real wastewater at large scale. Moreover, it is very important to introduce sustainable waste materials such as agricultural and industrial wastes in the production of new CPNs-based adsorbents. Also, the competitive applicability of these innovative adsorbents should be evaluated taking into account the various parameters linked to the material proprieties (material degradation, alteration, life cycle, and regeneration) and to the generated wastes including the disposal of the loaded pollutants and the chemicals used for the process of adsorption/desorption.

Author Contributions: Writing—original draft preparation, A.A., N.S.A., K.M.K., F.M.A., and M.A.T.; writing-review and editing, A.A., N.S.A., K.M.K., F.M.A., M.A.T., and F.B.R.; visualization; F.B.R. All authors have read and agreed to the published version of the manuscript. 
Funding: The authors extend their appreciation to the Deanship of Scientific Research at King Khalid University for funding this work through research groups program under grant number R.G.P.2/157/42. Also, this research was funded by the Deanship of Scientific Research at Princess Nourah bint Abdulrahman University through the Fast-track Research Funding Program.

Institutional Review Board Statement: Not applicable.

Informed Consent Statement: Not applicable.

Data Availability Statement: Data sharing is not applicable.

Conflicts of Interest: The authors declare no conflict of interest.

\section{References}

1. Jaishankar, M.; Tseten, T.; Anbalagan, N.; Mathew, B.B.; Beeregowda, K.N. Toxicity, mechanism and health effects of some heavy metals. Interdiscip. Toxicol. 2014, 7, 60-72. [CrossRef]

2. Jonathan, M.; Srinivasalu, S.; Thangadurai, N.; Ayyamperumal, T.; Armstrong-Altrin, J.; Ram-Mohan, V. Contamination of Uppanar River and coastal waters off Cuddalore, Southeast coast of India. Environ. Geol. 2008, 53, 1391-1404. [CrossRef]

3. Siddeeg, S.M.; Tahoon, M.A.; Ben Rebah, F. Simultaneous Removal of Calconcarboxylic Acid, NH4+ and PO43- from Pharmaceutical Effluent Using Iron Oxide-Biochar Nanocomposite Loaded with Pseudomonas putida. Processes 2019, 7, 800. [CrossRef]

4. Khulbe, K.C.; Matsuura, T. Removal of heavy metals and pollutants by membrane adsorption techniques. Appl. Water Sci. 2018, 8 , 1-30. [CrossRef]

5. Sahmoune, M.N. Evaluation of thermodynamic parameters for adsorption of heavy metals by green adsorbents. Environ. Chem. Lett. 2019, 17, 697-704. [CrossRef]

6. Chebotarevaa, R.D.; Remeza, S.V.; Bashtana, S.Y. Water Softening and Disinfection Using an Electrolysis Unit with a Filtering Cartridge. J. Water Chem. Technol. 2020, 42, 54-59. [CrossRef]

7. Al-Amshawee, S.; Yunus, M.Y.B.M.; Azoddein, A.A.M.; Hassell, D.G.; Dakhil, I.H.; Hasan, H.A. Electrodialysis desalination for water and wastewater: A review. Chem. Eng. J. 2020, 380, 122231. [CrossRef]

8. Liu, Z.; Lompe, K.M.; Mohseni, M.; Bérubé, P.R.; Sauvé, S.; Barbeau, B. Biological ion exchange as an alternative to biological activated carbon for drinking water treatment. Water Res. 2020, 68, 115148. [CrossRef]

9. Couto, C.F.; Santos, A.V.; Amaral, M.C.S.; Lange, L.C.; De Andrade, L.H.; Foureaux, A.F.S.; Fernandes, B.S. Assessing potential of nanofiltration, reverse osmosis and membrane distillation drinking water treatment for pharmaceutically active compounds (PhACs) removal. J. Water Process. Eng. 2020, 33, 101029. [CrossRef]

10. Skaf, D.W.; Punzi, V.L.; Rolle, J.T.; Kleinberg, K.A. Removal of micron-sized microplastic particles from simulated drinking water via alum coagulation. Chem. Eng. J. 2020, 386, 123807. [CrossRef]

11. Verma, B.; Balomajumder, C. Hexavalent chromium reduction from real electroplating wastewater by chemical precipitation. Bull. Chem. Soc. Ethiop. 2020, 34, 67-74. [CrossRef]

12. Khan, M.A.; Siddiqui, M.R.; Otero, M.; Alshareef, S.A.; Rafatullah, M. Removal of rhodamine b from water using a solvent impregnated polymeric dowex 5wx8 resin: Statistical optimization and batch adsorption studies. Polymers 2020, 12, 500. [CrossRef]

13. Coelho, C.M.; De Andrade, J.R.; Da Silva, M.G.C.; Vieira, M.G.A. Removal of propranolol hydrochloride by batch biosorption using remaining biomass of alginate extraction from Sargassum filipendula algae. Environ. Sci. Pollut. Res. 2020, 27, 16599-16611. [CrossRef] [PubMed]

14. Joseph, J.; Sajeesh, A.K.; Nagashri, K.; Gladis, E.E.; Sharmila, T.M.; Dhanaraj, C.J. Determination of ammonia content in various drinking water sources in Malappuram District, Kerala and its removal by adsorption using agricultural waste materials. Mater. Today 2020. [CrossRef]

15. He, P.; Ding, J.; Qin, Z.; Tang, L.; Haw, K.G.; Zhang, Y.; Valtchev, V. Binder-free preparation of ZSM-5@ silica beads and their use for organic pollutant removal. Inorg. Chem. Front. 2020, 7, 2080-2088. [CrossRef]

16. Thiebault, T. Raw and modified clays and clay minerals for the removal of pharmaceutical products from aqueous solutions: State of the art and future perspectives. Crit. Rev. Environ. Sci. Technol. 2020, 50, 1451-1514. [CrossRef]

17. Chen, X.; Yu, L.; Zou, S.; Xiao, L.; Fan, J. Zeolite cotton in tube: A Simple Robust Household Water treatment filter for Heavy Metal Removal. Sci. Rep. 2020, 10, 1-9. [CrossRef] [PubMed]

18. Nam, S.W.; Choi, D.J.; Kim, S.K.; Her, N.; Zoh, K.D. Adsorption characteristics of selected hydrophilic and hydrophobic micropollutants in water using activated carbon. J. Hazard. Mater. 2014, 270, 144-152. [CrossRef]

19. Unuabonah, E.I.; Taubert, A. Clay-polymer nanocomposites (CPNs): Adsorbents of the future for water treatment. Appl. Clay Sci. 2014, 99, 83-92. [CrossRef]

20. LeBaron, P.C.; Wang, Z.; Pinnavaia, T.J. Polymer-layered silicate nanocomposites: An overview. Appl. Clay Sci. 1999, 15, 11-29. [CrossRef]

21. Pavlidou, S.; Papaspyrides, C.D. A review on polymer-layered silicate nanocomposites. Prog. Polym. Sci. 2008, 32, 1119-1198. [CrossRef] 
22. Bergaya, F.; Detellier, C.; Lambert, J.F.; Lagaly, G. Introduction to Clay Polymer Nanocomposites (CPN). Chapter 13. In Handbook of Clay Science. Developments in Clay Science; Bergaya, L., Ed.; Elsevier: Amsterdam, The Netherlands, 2013 ; Volume 5.

23. Lee, S.M.; Tiwari, D. Organo and inorgano-organo-modifid clays in the remediation of aqueous solutions: An overview. Appl. Clay Sci. 2012, 59-60, 84-102. [CrossRef]

24. Konta, J. Clay and man: Clay raw materials in the service of man. Appl. Clay Sci. 1995, 10, 275-335. [CrossRef]

25. Sarkar, B.; Xi, Y.; Megharaj, M.; Krishnamurti, G.S.R.; Bowman, M.; Rose, H.; Naidu, R. Bioreactive organoclay: A new technology for environmental remediation. Crit. Rev. Environ. Sci. Technol. 2012, 42, 435-488. [CrossRef]

26. Mukhopadhyay, R.; De, N. Nano clay polymer composite: Synthesis, characterization, properties and application in rainfed agriculture. Glob. J. Biosci. Biotechnol. 2014, 3, 133-138.

27. Liu, Y.; Takafuji, M.; Ihara, H.; Wakiya, T. Saturation Magnetization of inorganic/ polymer Nanocomposites Higher Than That of Their Inorganic Magnetic Component. arXiv 2012, arXiv:1206.2805.

28. Rusmin, R.; Sarkar, B.; Tsuzuki, T.; Kawashima, N.; Naidu, R. Removal of lead from aqueous solution using superparamagnetic palygorskite nanocomposite: Material characterization and regeneration studies. Chemosphere 2017, 186, 1006-1015. [CrossRef] [PubMed]

29. Santos, V.P.; Marques, N.S.; Maia, P.C.; Lima, M.A.B.D.; Franco, L.D.O.; Campos-Takaki, G.M.D. Seafood Waste as Attractive Source of Chitin and Chitosan Production and Their Applications. Int. J. Mol. Sci. 2020, 21, 4290. [CrossRef] [PubMed]

30. Gogoi, P.; Thakur, A.J.; Devi, R.R.; Das, B.; Maji, T.K. A comparative study on sorption of arsenate ions from water by crosslinked chitosan and crosslinked chitosan/MMT nanocomposite. J. Environ. Chem. Eng. 2016, 4, 4248-4257. [CrossRef]

31. Biswas, S.; Rashid, T.U.; Debnath, T.; Haque, P.; Rahman, M.M. Application of chitosan-clay biocomposite beads for removal of heavy metal and dye from industrial effluent. J. Compos. Sci. 2020, 4, 16. [CrossRef]

32. Saurabh, K.; Kanchikeri, M.M.; Datta, S.C.; Thekkumpurath, A.S.; Kumar, R. Nanoclay polymer composites loaded with urea and nitrification inhibitors for controlling nitrification in soil. Arch. Agron. Soil. Sci. 2019, 65, 478-491. [CrossRef]

33. Burnside, S.D.; Emmanuel, P.G. Synthesis and properties of new poly (dimethylsiloxane) nanocomposites. Chem. Mate. 1995, 7, 1597-1600. [CrossRef]

34. Akelah, A.; Moet, A. Polymer-clay nanocomposites: Free-radical grafting of polystyrene on to organophilic montmorillonite interlayers. J. Mater. Sci. 1996, 31, 3589-3596. [CrossRef]

35. Vaia, R.A.; Giannelis, E.P. Lattice model of polymer melt intercalation in organically-modified layered silicates. Macromolecules. 1997, 30, 7990-7999. [CrossRef]

36. Ogata, N.; Jimenez, G.; Kawai, H.; Ogihara, T. Structure and thermal/mechanical properties of poly (l-lactide)-clay blend. J. Polym. Sci. B Polym Phys. 1997, 35, 389-396. [CrossRef]

37. Yano, K.; Usuki, A.; Okada, A.J.; Kurauchi, T.; Kamigaito, O.J. Synthesis and properties of polyimide-clay hybrid films. J. Polym. Sci. A Polym. Chem. 1997, 35, 2289. [CrossRef]

38. Wang, Z.; Pinnavaia, T.J. Hybrid organic- inorganic nanocomposites: Exfoliation of magadiite nanolayers in an elastomeric epoxy polymer. Chem. Mater. 1998, 10, 1820-1826. [CrossRef]

39. Wang, Z.; Pinnavaia, T.J. Nanolayer reinforcement of elastomeric polyurethane. Chem. Mater. 1998, 10, 3769-3771. [CrossRef]

40. Wołejko, E.; Wydro, U.; Butarewicz, A.; Jabłońska-Trypuć, A. Methods Used in Situ for Removal of Waterborne Pathogens. In Waterborne Pathogens; Butterworth-Heinemann: Oxford, UK, 2020; pp. 321-337.

41. Kaya, A.U.; Güner, S.; Ryskin, M.; Lameck, A.S.; Benitez, A.R.; Shuali, U.; Nir, S. Effect of Microwave Radiation on Regeneration of a Granulated Micelle-Clay Complex after Adsorption of Bacteria. Appl. Sci. 2020, 10, 2530. [CrossRef]

42. Farré, M.J.; Insa, S.; Lamb, A.; Cojocariu, C.; Gernjak, W. Occurrence of N-nitrosamines and their precursors in Spanish drinking water treatment plants and distribution systems. Environ. Sci. Wat. Res. 2020, 6, 210-220. [CrossRef]

43. Bruna, J.E.; Peñaloza, A.; Guarda, A.; Rodríguez, F.; Galotto, M.J. Development of Mt Cu2+ /LDPE nanocomposites with antimicrobial activity for potential use in food packaging. Appl. Clay Sci. 2012, 58, 79-87. [CrossRef]

44. Lejon, D.P.H.; Pascault, N.; Ranjard, L. Diffrential copper impact on density, diversity and resistance of adapted culturable bacterial populations according to soil organic status. Eur. J. Soil Biol. 2010, 46, 168-174. [CrossRef]

45. Zhou, N.L.; Liu, Y.; Li, L.; Meng, N.; Huang, Y.X.; Zhang, J.; Wei, S.H.; Shen, J. A new nanocomposite biomedical material of polymer/Clay-Cts-Ag nanocomposites. Curr. Appl. Phys. 2007, 7, 58-62. [CrossRef]

46. Kang, J.K.; Lee, C.G.; Park, J.A.; Kim, S.B.; Choi, N.C.; Park, S.J. Adhesion of bacteria to pyrophyllite clay in aqueous solution. Environ. Technol. 2013, 34, 703-710. [CrossRef]

47. Undabeytia, T.; Posada, R.; Nir, S.; Galindo, I.; Laiz, L.; Saiz-Jimenez, C.; Morillo, E. Removal of waterborne microorganisms by fitration using clay-polymer complexes. J. Hazard. Mater. 2014, 279, 190-196. [CrossRef]

48. Meng, N.; Zhou, N.-L.; Zhang, S.-Q.; Shen, J. Synthesis and antimicrobial activities of polymer/montmorillonite-chlorhexidine acetate nanocomposite fims. Appl. Clay Sci. 2009, 42, 667-670. [CrossRef]

49. Han, Y.-S.; Lee, S.-H.; Choi, K.H.; Park, I. Preparation and characterization of chitosan-clay nanocomposites with antimicrobial activity. J. Phys. Chem. Solids 2010, 71, 464-467. [CrossRef]

50. Motshekga, S.C.; Ray, S.S.; Onyango, M.S.; Momba, M.N.B. Preparation and antibacterial activity of chitosan-based nanocomposites containing bentonite-supported silver and zinc oxide nanoparticles for water disinfection. Appl. Clay Sci. 2015, 114, 330-339. [CrossRef] 
51. Deng, H.; Li, X.; Ding, B.; Du, Y.; Li, G.; Yang, J.; Hu, X. Fabrication of polymer/ layered silicate intercalated nanofirous mats and their bacterial inhibition activity. Carbohydr. Polym. 2011, 83, 973-978. [CrossRef]

52. Shameli, K.; Ahmad, M.B.; Mohsen, Z.; Yunis, W.Z.; Ibrahim, N.A.; Shabanzadeh, P.; Moghaddam, M.G. Synthesis and characterization of silver/montmorillonite/ chitosan bionanocomposites by chemical reduction method and their antibacterial activity. Int. J. Nanomed. 2011, 6, 271-284. [CrossRef]

53. Rhim, J.W.; Hong, S.I.; Park, H.M.; Ng, P.K.W. Preparation and characterization of chitosan-based nanocomposite fims with antimicrobial activity. J. Agric. Food Chem. 2006, 54, 5814-5822. [CrossRef] [PubMed]

54. Chi, W.; Qin, C.; Zeng, L.; Li, W.; Wang, W. Microbiocidal activity of chitosan-N-2- hydroxypropyl trimethyl ammonium chloride. J. Appl. Polym. Sci. 2007, 103, 3851-3856. [CrossRef]

55. Unuabonah, E.I.; Ugwuja, C.G.; Omorogie, M.O.; Adewuyi, A.; Oladoja, N.A. Clays for efficient disinfection of bacteria in water. Appl. Clay Sci. 2018, 151, 211-223. [CrossRef]

56. Unuabonah, E.I.; Kolawole, M.O.; Agunbiade, F.O.; Omorogie, M.O.; Koko, D.T.; Ugwuja, C.G.; Ugege, L.E.; Oyejide, N.E.; Günter, C.; Taubert, A. Novel metal-doped bacteriostatic hybrid clay composites for point-of-use disinfection of water. J. Environ. Chem. Eng. 2017, 5, 2128-2141. [CrossRef]

57. Momina, M.; Shahadat, S.I. Regeneration performance of clay-based adsorbents for the removal of industrial dyes: A review. RSC Adv. 2018, 8, 24571-24587. [CrossRef]

58. Deng, Y.; Wang, L.; Hu, X.; Liu, B.; Wei, Z.; Yang, S.; Sun, C. Highly efficient removal of tannic acid from aqueous solution by chitosan-coated attapulgite. Chem. Eng. J. 2012, 181, 300-306. [CrossRef]

59. $\mathrm{Wu}, \mathrm{J} . ;$ Chen, J. Adsorption characteristics of tannic acid onto the novel protonated palygorskite/chitosan resin microspheres. J. Appl. Polym. Sci. 2013, 127, 1765-1771. [CrossRef]

60. Hernández-Hernández, K.A.; Illescas, J.; Díaz-Nava, M.D.C.; Martínez-Gallegos, S.; MuroUrista, C.; Ortega-Aguilar, R.E.; Rodríguez-Alba, E.; Rivera, E. Preparation of nanocomposites for the removal of phenolic compounds from aqueous solutions. Appl. Clay Sci. 2018, 157, 212-217. [CrossRef]

61. Ganigar, R.; Rytwo, G.; Gonen, Y.; Radian, A.; Mishael, Y.G. Polymer-clay nanocomposites for the removal of trichlorophenol and trinitrophenol from water. Appl. Clay Sci. 2010, 49, 311-316. [CrossRef]

62. Zhu, J.; Wang, T.; Zhu, R.; Ge, F.; Wei, J.; Yuan, P.; He, H. Novel polymer/surfactant modified montmorillonite hybrids and the implications for the treatment of hydrophobic organic compounds in wastewaters. Appl. Clay Sci. 2011, 51, 317-322. [CrossRef]

63. Zadaka, D.; Nir, S.; Radian, A.; Mishael, Y.G. Atrazine removal from water by polycation-clay composites: Effct of dissolved organic matter and comparison to activated carbon. Water Res. 2009, 43, 677-683. [CrossRef]

64. Ghaemi, N.; Madaeni, S.S.; Alizadeh, A.; Rajabi, H.; Daraei, P. Preparation, characterization and performance of polyethersulfone/organically modifid montmorillonite nanocomposite membranes in removal of pesticides. J. Memb. Sci. 2011, 382, 135-147. [CrossRef]

65. Gámiz, B.; Hermosín, M.C.; Cornejo, J.; Celis, R. Hexadimethrine-montmorillonite nanocomposite: Characterization and application as a pesticide adsorbent. Appl. Surf. Sci. 2015, 332, 606-613. [CrossRef]

66. Wan Ngah, W.S.; Ariff, N.F.M.; Hanafih, M.A.K.M. Preparation, characterization, and environmental application of crosslinked chitosan-coated bentonite for tartrazine adsorption from aqueous solutions. Water Air Soil Pollut. 2010, 206, 225-236. [CrossRef]

67. Bée, A.; Obeid, L.; Mbolantenaina, R.; Welschbillig, M.; Talbot, D. Magnetic chitosan/clay beads: A magsorbent for the removal of cationic dye from water. J. Magn. Magn. Mater. 2017, 421, 59-64. [CrossRef]

68. Vanamudan, A.; Pamidimukkala, P. Chitosan, nanoclay and chitosan-nanoclay composite as adsorbents for Rhodamine-6G and the resulting optical properties. Int. J. Biol. Macromol. 2015, 74, 127-135. [CrossRef]

69. Xu, R.; Mao, J.; Peng, N.; Luo, X.; Chang, C. Chitin/clay microspheres with hierarchical architecture for highly efficient removal of organic dyes. Carbohydr. Polym. 2018, 188, 143-150. [CrossRef]

70. Vanaamudan, A.; Sudhakar, P.P. Equilibrium, kinetics and thermodynamic study on adsorption of reactive blue-21 and reactive red-141 by chitosan-organically modifid nanoclay (Cloisite 30B) nano-bio composite. J. Taiwan Inst. Chem. Eng. 2015, 55, 145-151. [CrossRef]

71. Peng, Y.; Chen, D.; Ji, J.; Kong, Y.; Wan, H.; Yao, C. Chitosan-modifid palygorskite: Preparation, characterization and reactive dye removal. Appl. Clay Sci. 2013, 74, 81-86. [CrossRef]

72. Wang, L.; Zhang, J.; Wang, A. Removal of methylene blue from aqueous solution using chitosan-g-poly(acrylic acid)/montmorillonite superadsorbent nanocomposite. Colloids Surf. A Physicochem. Eng. Asp. 2008, 322, 47-53. [CrossRef]

73. Wang, L.; Wang, A. Adsorption characteristics of Congo Red onto the chitosan/ montmorillonite nanocomposite. J. Hazard. Mater. 2007, 147, 979-985. [CrossRef] [PubMed]

74. Li, Q.; Yue, Q.; Su, Y.; Gao, B. Equilibrium and a two-stage batch adsorber design for reactive or disperse dye removal to minimize adsorbent amount. Bioresour. Technol. 2011, 102, 5290-5296. [CrossRef]

75. Kang, Q.; Zhou, W.; Li, Q.; Gao, B.; Fan, J.; Shen, D. Adsorption of anionic dyes on poly(epicholorohydrin dimethylamine) modifid bentonite in single and mixed dye solutions. Appl. Clay Sci. 2009, 45, 280-287. [CrossRef]

76. Anirudhan, T.S.; Suchithra, P.S.; Radhakrishnan, P.G. Synthesis and characterization of humic acid immobilized-polymer/bentonite composites and their ability to adsorb basic dyes from aqueous solutions. Appl. Clay Sci. 2009, 43, 336-342. [CrossRef] 
77. De Sousa, E.P.; De Araujo, D.T.; Peixoto, V.G.; Ferreira, B.F.; De Faria, E.H.; Molina, E.F. Effect of sodium bentonite content on structural-properties of ureasil poly (ethylene oxide)-PEO hybrid: A perspective for water treatment. Appl. Clay Sci. 2020, $191,105605$. [CrossRef]

78. Khalil, A.M.; Sayed, H.K. Hybrid Membranes Based on Clay-Polymer for Removing Methylene Blue from Water. Acta Chim. Slovenica. 2020, 67, 96-104. [CrossRef]

79. Azha, S.F.; Shamsudin, M.S.; Shahadat, M.; Ismail, S. Low cost zwitterionic adsorbent coating for treatment of anionic and cationic dyes. J. Ind. Eng. Chem. 2018, 67, 187-198. [CrossRef]

80. Kaşgöz, H.; Durmus, A. Dye removal by a novel hydrogel-clay nanocomposite with enhanced swelling properties. Polym. Adv. Technol. 2018, 19, 838-845. [CrossRef]

81. Jin, X.; Zheng, M.; Sarkar, B.; Naidu, R.; Chen, Z. Characterization of bentonite modifid with humic acid for the removal of Cu (II) and 2,4-dichlorophenol from aqueous solution. Appl. Clay Sci. 2016, 134, 89-94. [CrossRef]

82. Zhou, K.; Zhang, Q.; Wang, B.; Liu, J.; Wen, P.; Gui, Z.; Hu, Y. The integrated utilization of typical clays in removal of organic dyes and polymer nanocomposites. J. Clean. Prod. 2014, 81, 281-289. [CrossRef]

83. Liu, Q.; Yang, B.; Zhang, L.; Huang, R. Adsorption of an anionic azo dye by crosslinked chitosan/bentonite composite. Int. J. Biol. Macromol. 2015, 72, 1129-1135. [CrossRef] [PubMed]

84. Mahdavinia, G.R.; Asgari, A. Synthesis of kappa-carrageenan-g-poly(acrylamide)/ sepiolite nanocomposite hydrogels and adsorption of cationic dye. Polym. Bull. 2013, 70, 2451-2470. [CrossRef]

85. Hosseinzadeh, H.; Khoshnood, N. Removal of cationic dyes by poly(AA-co-AMPS)/ montmorillonite nanocomposite hydrogel. Desalin. Water Treat. 2016, 57, 6372-6383. [CrossRef]

86. Uyar, G.; Kaygusuz, H.; Erim, F.B. Methylene blue removal by alginate-clay quasicryogel beads. React. Funct. Polym. 2016, 106, 1-7. [CrossRef]

87. Wan Ngah, W.S.; Ariff, N.F.M.; Hashim, A.; Hanafih, M.A.K.M. Malachite green adsorption onto chitosan coated bentonite beads: Isotherms, kinetics and mechanism. Clean Soil Air Water 2010, 38, 394-400. [CrossRef]

88. Kalotraji, S.; Mehta, R. Synthesis of polyaniline/clay nanocomposites by in situ polymerization and its application for the removal of Acid Green 25 dye from wastewater. Polym. Bull. 2020. [CrossRef]

89. Saki, S.; Senol-Arslan, D.; Uzal, N. Fabrication and characterization of silane-functionalized Na-bentonite polysulfone/polyethylenimine nanocomposite membranes for dye removal. J. Appl. Polym. Sci. 2020, 137, 49057. [CrossRef]

90. Narayanan, N.; Gupta, S.; Gajbhiye, V.T. Decontamination of pesticide industrial effluent by adsorption-coagulation-flocculation process using biopolymer nanoorganoclay composite. Int. J. Environ. Sci. Technol. 2020, 17, 4775-4786. [CrossRef]

91. Zhang, A.C.; Sun, L.S.; Xiang, J.; Hu, S.; Fu, P.; Su, S.; Zhou, Y.B. Removal of elemental mercury from coal combustion flue gas by bentonite-chitosan and their modifier. J. Fuel Chem. Technol. 2009, 37, 489-495. [CrossRef]

92. Liu, E.; Sarkar, B.; Wang, L.; Naidu, R. Copper-complexed clay/poly-acrylic acid composites: Extremely efficient adsorbents of ammonia gas. Appl. Clay Sci. 2016, 121, 154-161. [CrossRef]

93. Jordao, C.; Pereira, M.; Pereira, J. Metal contamination of river waters and sediments from effluents of kaolin processing in Brazil. Water Air Soil Pollut. 2002, 140, 119-138. [CrossRef]

94. Azzam, E.M.S.; Eshaq, G.; Rabie, A.M.; Bakr, A.A.; Abd-Elaal, A.A.; El Metwally, A.E.; Tawfik, S.M. Preparation and characterization of chitosan-clay nanocomposites for the removal of $\mathrm{Cu}(\mathrm{II})$ from aqueous solution. Int. J. Biol. Macromol. 2016, 89, 507-517. [CrossRef] [PubMed]

95. Abdel, K.M.A.; Mahmoud, G.A.; El-Kelesh, N.A. Synthesis and characterization of poly-methacrylic acid grafted chitosanbentonite composite and its application for heavy metals recovery. Chem. Mater. Res. 2012, 2, 1-12.

96. Zou, X.; Pan, J.; Ou, H.; Wang, X.; Guan, W.; Li, C.; Yan, Y.; Duan, Y. Adsorptive removal of Cr(III) and Fe(III) from aqueous solution by chitosan/attapulgite composites: Equilibrium, thermodynamics and kinetics. Chem. Eng. J. 2011, 167, 112-121. [CrossRef]

97. Wang, Y.M.; Duan, L.; Sun, Y.; Hu, N.; Gao, J.Y.; Wang, H.; Xie, X.M. Adsorptive removal of Cr(VI) from aqueous solutions with an effective adsorbent: Cross-linked chitosan/montmorillonite nanocomposites in the presence of hydroxy-aluminum oligomeric cations. Desalin. Water Treat. 2016, 57, 10767-10775. [CrossRef]

98. Duan, L.; Hu, N.; Wang, T.; Wang, H.; Ling, L.; Sun, Y.; Xie, X. Removal of copper and lead from aqueous solution by adsorption onto cross-linked chitosan/montmorillonite nanocomposites in the presence of hydroxyl-aluminum oligomeric cations: Equilibrium, kinetic, and thermodynamic studies. Chem. Eng. Commun. 2016, 203, 28-36. [CrossRef]

99. Rusmin, R.; Sarkar, B.; Liu, Y.; McClure, S.; Naidu, R. Structural evolution of chitosan-palygorskite composites and removal of aqueous lead by composite beads. Appl. Surf. Sci. 2015, 353, 363-375. [CrossRef]

100. Alsewailem, F.D.; Aljlil, S.A. Recycled polymer/clay composites for heavy-metals adsorption. Mater. Technol. $2013,47,525-529$.

101. Msaadi, R.; Ammar, S.; Chehimi, M.M.; Yagci, Y. Diazonium-based ion-imprinted polymer/clay nanocomposite for the selective extraction of lead (II) ions in aqueous media. Eur. Polym. J. 2017, 89, 367-380. [CrossRef]

102. Kumararaja, P.; Manjaiah, K.M.; Datta, S.C.; Shabeer, A.T.P.; Sarkar, B. Chitosan-g-poly(acrylic acid)-bentonite composite: A potential immobilizing agent of heavy metals in soil. Cellulose 2018, 25, 3985-3999. [CrossRef]

103. Grisdanurak, N.; Akewaranugulsiri, S.; Futalan, C.M.; Tsai, W.C.; Kan, C.C.; Hsu, C.W.; Wan, M.W. The study of copper adsorption from aqueous solution using crosslinked chitosan immobilized on bentonite. J. Appl. Polym. Sci. 2012, 125, E132-E142. [CrossRef] 
104. Futalan, C.M.; Kan, C.C.; Dalida, M.L.; Hsien, K.J.; Pascua, C.; Wan, M.W. Comparative and competitive adsorption of copper, lead, and nickel using chitosan immobilized on bentonite. Carbohydr. Polym. 2011, 83, 528-536. [CrossRef]

105. Nunes, P.; Nagy, N.V.; Alegria, E.C.B.A.; Pombeiro, A.J.L.; Correia, I. The solvation and electrochemical behavior of copper acetylacetonate complexes in ionic liquids. J. Mol. Struct. 2014, 1060, 142-149. [CrossRef]

106. Yousef, W.M.; Alenezi, K.; Naggar, A.H.; Hassan, T.M.; Bortata, S.Z.; Farghaly, O.A. Potentiometric and Conductometric Studies on Complexes of Folic Acid with Some Metal Ions. Int. J. Electrochem. Sci. 2017, 12, 1146-1156. [CrossRef]

107. De, S.; Ali, S.M.; Ali, A.; Gaikar, V.G. Micro-solvation of the $\mathrm{Zn}^{2+}$ ion-A case study. Phys. Chem. Chem. Phys. 2009, 11, 8285-8294. [CrossRef] [PubMed]

108. Sarada, B.; Krishna Prasad, M.; Kishore Kumar, K.; Murthy, C.V.R. Biosorption of Cd ${ }^{2+}$ by green plant biomass, Araucaria heterophylla: Characterization, kinetic, isotherm and thermodynamic studies. Appl. Water Sci. 2017, 7, 3483-3496. [CrossRef]

109. Liu, X.; Lee, D.J. Thermodynamic parameters for adsorption equilibrium of heavy metals and dyes from wastewaters. Bioresour Technol. 2014, 160, 24-31. [CrossRef]

110. Sahmoune, M.N. The role of biosorbents in the removal of arsenic from water. Chem. Eng. Technol. 2016, 39, 1617-1628. [CrossRef]

111. Jana, S.; Saikia, A.; Purkait, M.K.; Mohanty, K. Chitosan based ceramic ultrafiltration membrane: Preparation, characterization and application to remove $\mathrm{Hg}(\mathrm{II})$ and As(III) using polymer enhanced ultrafiltration. Chem. Eng. J. 2011, 170, 209-219. [CrossRef]

112. Urbano, B.F.; Rivas, B.L.; Martinez, F.; Alexandratos, S.D. Water-insoluble polymer-clay nanocomposite ion exchange resin based on N-methyl-d-glucamine ligand groups for arsenic removal. React. Funct. Polym. 2012, 72, 642-649. [CrossRef]

113. Sundaram, E.J.S.; Dharmalingam, P. Synthesis and characterization of magnetized clay polymer nanocomposites and its adsorptive behaviour in removal of $\mathrm{Cr}(\mathrm{VI})$ from aqueous phase. Asian J. Chem. 2018, 30, 667-672. [CrossRef]

114. Ravikumar, K.; Udayakumar, J. Preparation and characterisation of green clay-polymer nanocomposite for heavy metals removal. Chem Ecol. 2020, 36, 270-291. [CrossRef]

115. Liu, X.; Cheng, C.; Xiao, C.; Shao, D.; Xu, Z.; Wang, J.; Hu, S.; Li, X.; Wang, W. Polyaniline (PANI) modified bentonite by plasma technique for U(VI) removal from aqueous solution. Appl. Surf. Sci. 2017, 411, 331-337. [CrossRef]

116. El-Korashy, S.A.; Elwakeel, K.Z.; El-Hafeiz, A.A. Fabrication of bentonite/thioureaformaldehyde composite material for Pb(II), $\mathrm{Mn}(\mathrm{VII})$ and $\mathrm{Cr}(\mathrm{VI})$ sorption: A combined basic study and industrial application. J. Clean. Prod. 2016, 137, 40-50. [CrossRef]

117. Shawky, H.A. Improvement of water quality using alginate/montmorillonite composite beads. J. Appl. Polym. Sci. 2011, 119, 2371-2378. [CrossRef]

118. Saravanan, D.; Gomathi, T.; Sudha, P.N. Sorption studies on heavy metal removal using chitin/bentonite biocomposite. Int. J. Biol. Macromol. 2013, 53, 67-71. [CrossRef] [PubMed]

119. Kumar, A.S.K.; Kalidhasan, S.; Rajesh, V.; Rajesh, N. Application of cellulose-clay composite biosorbent toward the effective adsorption and removal of chromium from industrial wastewater. Ind. Eng. Chem. Res. 2012, 51, 58-69. [CrossRef]

120. Wang, X.; Yang, L.; Zhang, J.; Wang, C.; Li, Q. Preparation and characterization of chitosan-poly(vinyl alcohol)/bentonite nanocomposites for adsorption of $\mathrm{Hg}$ (II) ions. Chem. Eng. J. 2014, 251, 404-412. [CrossRef]

121. Bleiman, N.; Mishael, Y.G. Selenium removal from drinking water by adsorption to chitosan-clay composites and oxides: Batch and columns tests. J. Hazard. Mater. 2010, 183, 590-595. [CrossRef]

122. Anirudhan, T.S.; Rijith, S.; Tharun, A.R. Adsorptive removal of thorium (IV) from aqueous solutions using poly(methacrylic acid)-grafted chitosan/bentonite composite matrix: Process design and equilibrium studies. Colloids Surf. A Physicochem. Eng. Asp. 2010, 368, 13-22. [CrossRef]

123. Ahmad, R.; Hasan, I. L-cystein modified bentonite-cellulose nanocomposite (cellu/cys-bent) for adsorption of $\mathrm{Cu}^{2+}, \mathrm{Pb}^{2+}$, and $\mathrm{Cd}^{2+}$ ions from aqueous solution. Sep. Sci. Technol. 2016, 51, 381-394. [CrossRef]

124. Liu, P.; Jiang, L.; Zhu, L.; Guo, J.; Wang, A. Synthesis of covalently crosslinked attapulgite/poly(acrylic acid-co-acrylamide) nanocomposite hydrogels and their evaluation as adsorbent for heavy metal ions. J. Ind. Eng. Chem. 2015, 23, 188-193. [CrossRef]

125. Saber-Samandari, S.; Saber-Samandari, S.; Gazi, M. Cellulose-graft-polyacrylamide/hydroxyapatite composite hydrogel with possible application in removal of $\mathrm{Cu}$ (II) ions. React. Funct. Polym. 2013, 73, 1523-1530. [CrossRef]

126. Dinu, M.V.; Dragan, E.S. Evaluation of $\mathrm{Cu} 2+, \mathrm{Co} 2+$ and Ni2+ ions removal from aqueous solution using a novel chitosan/clinoptilolite composite: Kinetics and isotherms. Chem. Eng. J. 2010, 160, 157-163. [CrossRef]

127. Yadav, V.B.; Gadi, R.; Kalra, S. Clay based nanocomposites for removal of heavy metals from water: A review. J. Environ. Manage. 2019, 232, 803-817. [CrossRef] [PubMed]

128. Dlamini, D.S.; Mishra, A.K.; Mamba, B.B. ANN modeling in Pb(II) removal from water by clay-polymer composites fabricated via the melt-blending. J. Appl. Polym. Sci. 2013, 130, 3894-3901. [CrossRef]

129. Liu, P.; Jiang, L.; Zhu, L.; Wang, A. Novel approach for attapulgite/poly(acrylic acid) (ATP/PAA) nanocomposite microgels as selective adsorbent for $\mathrm{Pb}$ (II) Ion. React. Funct. Polym. 2014, 74, 72-80. [CrossRef]

130. Eibagi, H.; Faghihi, K. Preparation of thermally stable magnetic poly (urethane-imide)/nanocomposite containing $\beta$-cyclodextrin cavities as new adsorbent for lead and cadmium. J. Polym. Res. 2020, 27, 1-14. [CrossRef]

131. Sari, A.; Tuzen, M. Cd (II) adsorption from aqueous solution by raw and modified kaolinite. Appl. Clay Sci. 2014, 88, 63-72. [CrossRef]

132. Styszko, K.; Nosek, K.; Motak, M.; Bester, K. Preliminary selection of clay minerals for the removal of pharmaceuticals, bisphenol A and triclosan in acidic and neutral aqueous solutions. C. R. Chim. 2015, 18, 1134-1142. [CrossRef] 
133. Anirudhan, T.S.; Ramachandran, M. Synthesis and characterization of amidoximated polyacrylonitrile/organobentonite composite for $\mathrm{Cu}$ (II), Zn (II), and Cd (II) adsorption from aqueous solutions and industry wastewaters. Ind. Eng. Chem. Res. 2008, 47, 6175-6184. [CrossRef]

134. Aydin, A.H.; Yavuz, Ö. Removal of acid red 183 from aqueous solution using clay and activated carbon. Indian J. Chem. Technol. 2004, 11, 201.

135. Unuabonah, E.I.; Adebowale, K.O.; Olu-Owolabi, B.I.; Yang, L.Z. Comparison of sorption of $\mathrm{Pb}^{2+}$ and $\mathrm{Cd}^{2+}$ on kaolinite clay and polyvinyl alcohol-modified kaolinite clay. Adsorption 2008, 14, 791-803. [CrossRef] 